\title{
CALM LIKE A BOMB: \\ An Assessment of the Partial Defence of Provocation
}

\author{
WAYNE N. RENKE*
}

The partial defence of provocation has been used by the common law courts for some 400 years. Recently, it has been attacked for promoting male heterosexual violence and for its presupposition that ordinary people fly into homicidal rages. The author examines the provocation doctrine and argues that while some changes can be made to the drafting and deployment of the defence, provocation serves a legitimate purpose in accounting for the complexity of being human. The author supports this position by reviewing the application of the doctrine, addressing common criticisms of the defence, and suggesting improvements to the application of provocation that will prevent it from being used to devalue and degrade murder victims.
Les tribunaux de common law utilisent la défense partielle de provocation depuis environ 400 ans. Dernièrement, cette défense a été attaquée pour promotion de la violence hétérosexuelle mâle et sa présupposition que les gens ordinaires sont soudainement épris d'une rage meurtrière. L'auteur examine la doctrine de la provocation et fait valoir qu'alors que certains changements peuvent être faits à la formulation et l'utilisation de la défense, la provocation a une raison d'être légitime en expliquant la complexité de l'être humain. L'auteur est d'accord avec ce point de vue et examine l'application de la doctrine, aborde les critiques courantes de la défense et suggère des améliorations à l'application de la provocation pour l'empêcher d'être utilisée pour dévaluer et dégrader les victimes de meurtre.

\section{TABLE OF CONTENTS}

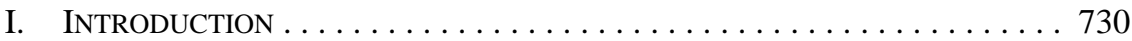

II. OvERVIEW . . . . . . . . . . . . . . . . . . . . . . . . . . 730

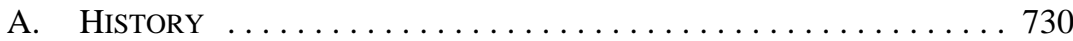

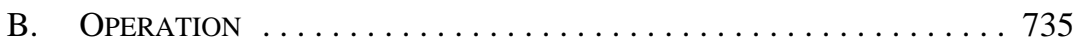

III. The CulPABILITY of A Provoked ACCUSED $\ldots \ldots \ldots \ldots \ldots \ldots \ldots 750$

A. JustificAtion OR EXCUSE? . . . . . . . . . . . . . . . . . 750

B. In What LiES THE EXCUSE? WRONGFUL ACt OR INSULT . . . . . . . 754

C. IN WHAT LIES THE EXCUSE?

THE ACCuSED's SubJeCtive ResPonse . . . . . . . . . . . . . . 759

D. In What Lies the Excuse? The ObJective ELEMENT … . . 767

IV. RECOMMENDATIONS FOR APPLYING THE

PRovocation DEFENCE . . . . . . . . . . . . . . . . . . . . . . . . . . . 774

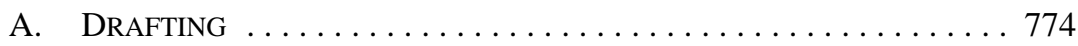

B. TRIAL JUdge AS GATEKEEPER $\ldots \ldots \ldots \ldots \ldots \ldots \ldots \ldots \ldots \ldots$

C. CHARge to the JuRY $\ldots \ldots \ldots \ldots \ldots \ldots \ldots \ldots$. . . . . . . . . . . 777

V. CONCLUSION ............................... 778

Professor and Vice-Dean, Faculty of Law, University of Alberta. Special thanks are due to my research assistant, Megan Howery (University of Alberta LL.B., Class of 2010). Those who know Megan will have no difficulty in accepting that any errors or omissions are mine. 


\section{INTRODUCTION}

There's a right to obey

And a right to kill. ${ }^{1}$

Why should not the partial defence of provocation be repealed? It has been attacked for promoting male heterosexual violence and blaming victims, and for its presupposition that ordinary people fly into homicidal rages. The defence, however, serves a legitimate purpose. While some improvements could be made to the drafting of the provocation provisions, the overall structure of the defence should be maintained. The real problems linked to the application of the defence - and they are real problems - should be addressed by trial judges in their determinations of whether the defence should be put to juries and in their jury instructions. To establish my claims, I will provide an overview of the history and operation of Canadian provocation doctrine, discuss the nature of the provocation defence and defend it against some challenges, and make some recommendations for the proper deployment of the defence. ${ }^{2}$

\section{OVERVIEW}

My comments on the history and operation of the provocation defence are intended to provide the context for the discussions in Parts III and IV. Elaborations on the moral and practical issues raised in Part II will be found there.

\section{A. HISTORY}

Provocation is a remarkably resilient doctrine. The common law defence of provocation began to crystallize in a form recognizable to modern eyes in the 1500s. ${ }^{3}$ The doctrine was established as a concession to human frailty, since "all human beings are subject to uncontrollable outbursts of passion and anger which may lead them to do violent acts." Provocation had three functions. First, from its inception, it was a partial defence, reducing the classification of what would otherwise be murder to manslaughter. ${ }^{5}$ The doctrine recognized that not all intentional killings are equally blameworthy, that provoked killings

Rage Against the Machine, “Calm Like a Bomb,” The Battle of Los Angeles (2 November 1999), lyrics by Zack de la Rocha.

2 I shall generally use the term "defence" in place of "partial defence" to describe the provocation doctrine.

3 In R.v. Mawgridge (1708), 84 E.R. 1107 (Q.B.) [Mawgridge], Holt C.J. provided a summary of the development of murder and provocation doctrine, and a review of the first century of provocation cases; see also Canada, Department of Justice, Reforming Criminal Code Defences: Provocation, Self-Defence and Defence of Property, A Consultation Paper (Ottawa: Justice Canada, 1998) at 2 [Justice Canada, Provocation]. Jeremy Horder traces the roots of the provocation doctrine into the medieval period: Jeremy Horder, Provocation and Responsibility (Oxford: Clarendon Press, 1992) c. 1.

$4 \quad$ R. v. Hill, [1986] 1 S.C.R. 313 at para. 14 [Hill]. See also John Royley's Case (1791), 79 E.R. 254 at 254 (K.B.): "And all the Court resolved, that it was but manslaughter; for he going upon the complaint of his son, not having any malice before, and in that anger beating him, of which stroke he died, the law shall adjudge it to be upon that sudden occasion and stirring of blood, being also provoked at the sight of his son's blood, that he made that assault, and will not presume it to be upon any former malice, unless it be found"; Sir Michael Foster, Report of Some Proceedings on the Commission for the Trial of the Rebels in the Year 1746, in the county of Surry; and of other Crown Cases: to which are added Discourses upon a Few Branches of the Crown Law, 3d ed. (London: W. Clarke and Sons, 1809) at 290; D.P.P. v. Camplin, [1978] 2 W.L.R. 679 at 681-82 (H.L.), Lord Diplock [Camplin]. 
are less blameworthy than intentional killings, but that provoked killings should still be punished. ${ }^{6}$ Second, when the provocation doctrine emerged, the punishment for murder was death. ${ }^{7}$ The practical effect of classifying a provoked killing as manslaughter was to avoid the imposition of capital punishment and to permit sentencing that reflected the blameworthiness of the crime. Third, a rule emerged early in the common law that upon proof that an accused caused a victim's death, "malice aforethought” would be presumed (the mens rea for murder). ${ }^{8}$ That presumption could be rebutted by proof of provocation, as well as by proof of other defences.

Until the late nineteenth century, the common law employed a "categorical” approach to provocation. ${ }^{9}$ Decisions identified a fixed list of types of situations that, as a matter of law, could constitute provocation. If a trial judge determined that the evidence could fit within one of these categories, the judge would put provocation to the jury, which in turn would decide whether or not the defence was made out. By the mid-nineteenth century, the recognized types of provocation were as follows: ${ }^{10}$

(i) an assault on the accused;

(ii) an assault (generally) on a friend or relative of the accused; ${ }^{11}$

(iii) illegal arrest of the accused;

(iv) the observation by the accused of his wife committing adultery;

$6 \quad$ "These considerations appear to me to show that murder, however accurately defined, must always admit of degrees of guilt; and it seems to me to follow that some discretion in regard to punishment ought also to be provided in this as in nearly every case”: Sir James Fitzjames Stephen, A History of the Criminal Law of England (London: MacMillan, 1883) vol. 3 at 85 [Stephen, History]; Bernard J. Brown, "The Demise of Chance Medley and the Recognition of Provocation as a Defence to Murder in English Law" (1963) 7 Am. J. Legal Hist. 310.

7 "Manslaughter was originally a clergyable felony, punishable under the statutes already referred to with burning in the hand and imprisonment for not exceeding a year": Stephen, History, ibid. at 78.

"In every charge of murder, the fact of killing being first proved, all the circumstances of accident, necessity, or infirmity are to be satisfactorily proved by the prisoner, unless they arise out of the evidence produced against him; for the law presumeth the fact to have been founded in malice, until the contrary appeareth": Foster, supra note 4 at 255 [emphasis in original]. This passage will be familiar to students of Anglo-Canadian law from its feature role in Woolmington v. D.P.P., [1935] 1 A.C. 462 (H.L.); see also Robert B. Mison, "Homophobia in Manslaughter: The Homosexual Advance as Insufficient Provocation” (1992) 80 Cal. L. Rev. 133 at 137; G.R. Sullivan, “Anger and Excuse: Reassessing Provocation” (1993) 13 Oxford J. Legal Stud. 421 at 422.

$9 \quad$ Cynthia Lee, Murder and the Reasonable Man: Passion and Fear in the Criminal Courtroom (New York: New York University Press, 2003) at 19. Horder argues that we should not exaggerate the continuity between the early modern jurisprudence (the categorical approach to provocation) and the later antecedents of our doctrine. His thesis is that the categories reflected an "honour code"; and, far from depending on the notion of "loss of self-control," the reaction of a provoked accused was understood as a not-too-great departure from the appropriate response to the provocation (excess beyond the mean of virtue): Horder, supra note 3 at 40, 56-57.

$10 \quad$ Lee, ibid. at 19, 22; Sullivan, supra note 8 at 422; Mawgridge, supra note 3 at 1114-15; Sir James Fitzjames Stephen, A Digest of the Criminal Law (Crimes and Punishments) (St. Louis: F.H. Thomas, 1878) at 165 [Stephen's Digest].

11 Which would include the observation of the act of sodomy committed upon a man's son: see R. v. Fisher (1837), 173 E.R. 452 (K.B.). 
(v) combat involving the accused (a quarrel and fight on equal terms and upon the spot — not an arranged duel). ${ }^{12}$

The common law categorical doctrine had several noteworthy features. Neither words nor gestures were recognized as provocative acts. ${ }^{13}$ Neither were injuries to property or breaches of contract. ${ }^{14}$ The act performed by the accused when allegedly provoked was assessed in the determination of whether the accused was provoked. ${ }^{15}$ The categorical approach did not employ any explicit objective test to determine whether provocation could be available in particular circumstances - the job of sorting “excusable” from "non-excusable” violence was done through the identified categories. By the nineteenth century, the state of mind of the accused became a focus of the provocation analysis. Provocation was available only if passion “deprived [the accused] of the power of self-control.”16

The categorical approach was, at least in part, tainted in its inception. Aside from the protection it extended to violence (much more about this below), the doctrine expressly reinforced the status of wives as the property of their husbands. No deep analysis or interpretation is necessary to establish this function of the defence. Commenting on the availability of provocation for a husband who witnessed his wife's adultery, Holt C.J. stated that "jealousy is the rage of a man, and adultery is the highest invasion of property.""17

The categorical approach was important to the development of Canadian criminal law. G.W. Burbidge's A Digest of the Criminal Law of Canada, an influential collection of principles and cases, ${ }^{18}$ followed the common law categorical approach to provocation. ${ }^{19}$ Burbidge's Digest was an express adaptation of Sir James Fitzjames Stephen's A Digest of the Criminal Law (Crimes and Punishments). ${ }^{20}$ Stephen's Digest synthesized the nearly 300 years of categorical provocation jurisprudence.

G.W. Burbidge, A Digest of the Criminal Law of Canada (Toronto: Carswell, 1890) at 220 [Burbidge’s Digest]; Stephen, History, supra note 6 at 100; Brown, supra note 6 at 313; Jeremy Horder, "The Duel and the English Law of Homicide” (1992) 12 Oxford J. Legal Stud. 419 at 424-25; Horder, supra note 3 at 29; Graeme Coss, “'God is a righteous judge, strong and patient: and God is provoked every day.' A Brief History of the Doctrine of Provocation in England” (1991) 13 Sydney L. Rev. 570 at 587. Prior to the nineteenth century, a separate doctrine of "chance-medley manslaughter" applied respecting death inflicted during combat (not including duels). The circumstances covered by chance-medley came to be absorbed under the provocation doctrine. Australia, New South Wales, Law Reform Commission, Partial Defences to Murder: Provocation and Infanticide (Report 83) (1997) at para. 2.3, online: Law Link <http://www.lawlink.nsw.gov.au/lrc.nsf/pages/R83TOC> [NSW LRC, Report].

$13 \quad$ Mawgridge, supra note 3 at 1112; Coss, ibid. at 575; Stephen’s Digest, supra note 10 at 165.

14 Stephen's Digest, ibid.

$15 \quad$ Ibid. at 167; Mawgridge, supra note 3 at 1113.

16 Stephen's Digest, ibid.; see also Sullivan, supra note 8 at 423 . Horder's view is that the focus on the accused's state of mind marked a decisive shift in the conceptual background to provocation. The older categorical approach relied on an understanding of emotion as controlled by reason; the anger driving provocation was in the nature of outrage: see Horder, supra note 3 at 72-73. In Horder's estimation, the more modern approach understood strong passion to eclipse reason (at 68, 74-75, 77, 83).

$17 \quad$ Mawgridge, supra note 3 at 1115.

18 The Digest "achieved instant fame in 1892, when the Attorney General, in introducing the Bill for Canada's first comprehensive Code, referred to Burbidge as a major source for this new legislation, and so it was”: The Honourable Mr. Justice Fred Kaufman, "Foreward,” in Burbidge’s Digest, supra note 12.

19 Burbidge's Digest, ibid., arts. 280-82.

20 Stephen's Digest, supra note 10. The title page of Burbidge's Digest states “founded by permission on Sir James Fitzjames Stephen's Digest of the Criminal Law.” 
In 1869, a new approach to provocation emerged, signalled by Keating J.'s decision in Welsh. ${ }^{21}$ The new approach abandoned the legal categories of provocation. Instead, whether provocation was available on the evidence was to be left to the jury, which was to employ an "ordinary person" test. Provocation would be recognized only if, in the circumstances, the ordinary person would have lost self-control. ${ }^{22}$ While Stephen did not refer to Welsh and the new approach to provocation in either his Digest or A History of the Criminal Law of England, Stephen was a member of the Royal Commission Appointed to Consider the Law Relating to Indictable Offences that prepared a Draft Criminal Code for England. ${ }^{23}$ The Draft Code addressed provocation in s. 176, which did not follow the categorical approach, but instead adopted the ordinary person approach:

Culpable homicide, which would otherwise be murder, may be reduced to manslaughter if the person who causes death does so in the heat of passion caused by sudden provocation.

Any wrongful act or insult of such a nature as to be sufficient to deprive an ordinary person of the power of self-control may be provocation, if the offender acts upon it on the sudden and before there has been time for his passion to cool.

Whether any particular wrongful act or insult, whatever may be its nature, amounts to provocation, and whether the person provoked was actually deprived of the power of self-control by the provocation which he received, shall be questions of fact: Provided that no one shall be deemed to give provocation to another only by doing that which he had a legal right to do, or by doing anything which the offender incited him to do in order to provide the offender with an excuse for killing or doing bodily harm to any person:

Provided also, that an arrest shall not necessarily reduce the offence from murder to manslaughter because the arrest was illegal, but if the illegality was known to the offender it may be evidence of provocation. ${ }^{24}$

The Draft Code was not enacted in England. It became, however, a foundation of Canada's 1892 Criminal Code ${ }^{25}$ Provocation was introduced in statutory form as s. 229 of the Criminal Code, 1892, which mirrored s. 176 of the Draft Code. ${ }^{26}$ The provocation provisions have persisted through multiple revisions of the Criminal Code, subject only to

"It would appear that Keating J. in Reg. v. Welsh (1869), 11 Cox C.C. 336 [Welsh] was the first to make use of the reasonable man as the embodiment of the standard of self-control required by the criminal law of persons exposed to provocation": Camplin, supra note 4 at 682. Lee, supra note 9 at 25.

U.K., Royal Commission Appointed to Consider the Law Relating to Indictable Offences, Appendix to the Report of the Commissioners containing the Draft Code (London: Her Majesty's Stationery Office, 1879), online: François Lareau <http://www.lareau-legal.ca/EnglishDraft CodeTWO.pdf > [Draft Code]; see Taylor v. R., [1947] S.C.R. 462 [Taylor].

$24 \quad$ Draft Code, ibid., s. 176 [footnotes omitted].

25

Along with Burbidge's Digest and earlier Canadian statutes: see Desmond Brown, The Birth of a Criminal Code: The Evolution of Canada's Justice System (Toronto: University of Toronto Press, 1995) at 34, 258; Law Reform Commission of Canada, Homicide (Working Paper 33) (Ottawa: Minister of Supply and Services Canada, 1984) at 8 [LRCC, Homicide].

26 Criminal Code, 1892, S.C. 1892, c. 29. 
minor amendments. ${ }^{27}$ The perseverance of the original drafting can be seen by a comparison of the 1892 and current Criminal Code provisions.

\begin{tabular}{|c|c|}
\hline Criminal Code, 1892, S.C. 1892 , c. 29 & Criminal Code, R.S.C. 1985, c. C-46 \\
\hline $\begin{array}{l}\text { 229. Provocation - Culpable homicide, which } \\
\text { would otherwise be murder, may be reduced to } \\
\text { manslaughter if the person who causes death does } \\
\text { so in the heat of passion caused by sudden } \\
\text { provocation. }\end{array}$ & $\begin{array}{l}\text { 232(1) Culpable homicide that otherwise would be } \\
\text { murder may be reduced to manslaughter if the } \\
\text { person who committed it did so in the heat of } \\
\text { passion caused by sudden provocation. }\end{array}$ \\
\hline $\begin{array}{l}\text { 2. Any wrongful act or insult, of such a nature as } \\
\text { to be sufficient to deprive an ordinary person of } \\
\text { the power of self-control, may be provocation if } \\
\text { the offender acts upon it on the sudden, and } \\
\text { before there has been time for his passion to cool. }\end{array}$ & $\begin{array}{l}\text { (2) A wrongful act or an insult that is of such a } \\
\text { nature as to be sufficient to deprive an ordinary } \\
\text { person of the power of self-control is provocation } \\
\text { for the purposes of this section if the accused acted } \\
\text { on it on the sudden and before there was time for } \\
\text { his passion to cool. }\end{array}$ \\
\hline $\begin{array}{l}\text { 3. Whether or not any particular wrongful act or } \\
\text { insult amounts to provocation, and whether or not } \\
\text { the person provoked was actually deprived of the } \\
\text { power of self-control by the provocation which he } \\
\text { received, shall be questions of fact. No one shall } \\
\text { be held to give provocation to another by doing } \\
\text { that which he had a legal right to do, or by doing } \\
\text { anything which the offender incited him to do in } \\
\text { order to provide the offender with an excuse for } \\
\text { killing or doing bodily harm to any person. }\end{array}$ & $\begin{array}{l}\text { (3) For the purposes of this section, the questions } \\
\text { (a) whether a particular wrongful act or insult } \\
\text { amounted to provocation, and } \\
\text { (b) whether the accused was deprived of the } \\
\text { power of self-control by the provocation that he } \\
\text { alleges he received, } \\
\text { are questions of fact, but no one shall be deemed to } \\
\text { have given provocation to another by doing } \\
\text { anything that he had a legal right to do, or by doing } \\
\text { anything that the accused incited him to do in order } \\
\text { to provide the accused with an excuse for causing } \\
\text { death or bodily harm to any human being. }\end{array}$ \\
\hline $\begin{array}{l}\text { 4. An arrest shall not necessarily reduce the } \\
\text { offence from murder to manslaughter because the } \\
\text { arrest was illegal, but if the illegality was known } \\
\text { to the offender it may be evidence of provocation. }\end{array}$ & $\begin{array}{l}\text { (4) Culpable homicide that otherwise would be } \\
\text { murder is not necessarily manslaughter by reason } \\
\text { only that it was committed by a person who was } \\
\text { being arrested illegally, but the fact that the } \\
\text { illegality of the arrest was known to the accused } \\
\text { may be evidence of provocation for the purpose of } \\
\text { this section. }\end{array}$ \\
\hline
\end{tabular}

Section 229 was re-enacted, with minor stylistic changes and the addition of marginal notes, as s. 261 of the 1906 Criminal Code: Criminal Code, R.S.C. 1906, c. 146. The section was unchanged in the 1927 revisions to the Criminal Code: Criminal Code, R.S.C. 1927, c. 36. It was re-enacted as s. 203 in the 1953-54 revision of the Criminal Code, with minor changes in wording: Criminal Code, S.C. 1953-54, c. 51. This version of the defence was re-enacted without changes in the 1970 Criminal Code: Criminal Code, R.S.C. 1970, c. C-34 and the 1985 Criminal Code: Criminal Code, R.S.C. 1985, c. C-46 [Criminal Code]. 
The statutorily adopted test preserved the focus on the role of passion in depriving the accused of the power of self-control found in the later categorical jurisprudence. Provocation could now include not only physical assaults, but insults. The requirement to consider the acts of the accused while allegedly under the sway of provocation was eliminated.

One might comment that the shift to the ordinary person approach was a positive step, since it expanded the scope of the defence and allowed juries to consider the particular circumstances of homicides. It also eliminated a nearly express declaration of the proprietary status of wives. Others might reply that oppressive conceptualizations were not eliminated but elided, moved from the express to the implicit, shifted from the judges to the silent work of the jury - the taint went underground. ${ }^{28}$

\section{B. OPERATION}

\section{Availability AND EFFECT OF THE DEFENCE}

Provocation is available only if an accused is charged with intentional homicide "[c]ulpable homicide that otherwise would be murder." ${ }^{29}$ Provocation is not a defence of general application. ${ }^{30}$ The scope of the defence is limited for two reasons. First, the sentencing regime for murder is rigid. Both first and second degree murder are punished by a mandatory minimum sentence of life imprisonment. ${ }^{31}$ The sentencing judge has no discretion to impose a lesser sentence based on the circumstances of the offence. In contrast, manslaughter is punishable by a maximum sentence of life imprisonment, which gives the sentencing judge wide latitude to take into account the particular circumstances of an offence. $^{32}$ Second, the legal label "murder" applies to some of the most serious offences against the person: "[a] conviction for murder carries with it the most severe stigma and punishment of any crime in our society." ${ }^{\text {"3 }}$ The severity of the stigma and punishment for murder give heightened importance to the circumstances that should reduce or eliminate that stigma or punishment. But not all intentional homicides deserve the same levels of condemnation:

Murder, as every practitioner of the law knows, though often described as one of the utmost heinousness, is not in fact necessarily so, but consists in a whole bundle of offences of vastly differing degrees of

Lee, supra note 9 at 65.

Criminal Code, supra note 27, s. 232(1).

R. v. Campbell (1977), 17 O.R. (2d) 673 at 682 (C.A.) [Campbell]; R. v. McDonald, 2005 BCSC 473, 71 W.C.B. (2d) 493 at para. 57 [McDonald]; LRCC, Homicide, supra note 25 at 72; Don Stuart, Canadian Criminal Law: A Treatise, 5th ed. (Scarborough: Thomson Carswell, 2007) at 559.

31 Criminal Code, supra note 27, ss. 235, 745. Under 235(1), “[e]very one who commits first degree murder or second degree murder is guilty of an indictable offence and shall be sentenced to imprisonment for life.” Under s. 235(2), "the sentence of imprisonment for life prescribed by this section is a minimum punishment." For first degree murder, parole eligibility is available only after 25 years of the sentence have been served (s. 745(a)). For second degree murder, parole eligibility is generally available only after 10-25 years of the sentence have been served (ss. 745(c), 745.2, 745.4). A person convicted of murder who is not eligible for parole until more than 15 years of his or her sentence have been served and who has served at least 15 years of his or her sentence may make an application for a reduction of the parole eligibility period (s. 745.6).

32 Ibid., s. 236(b). However, if a firearm is used in the commission of the offence, the offender is subject additionally to a minimum punishment of imprisonment for four years: see s. 236(a).

R. v. Martineau, [1990] 2 S.C.R. 633 at 645 [Martineau]. 
culpability, ranging from brutal, cynical and repeated offences like the so called Moors murders to the almost venial, if objectively immoral, "mercy killing” of a beloved partner. ${ }^{34}$

Through the provocation provisions, Parliament manifests the view that provocation should be taken into account as a mitigating factor. Provoked homicides should not be labelled as murder, and the provoked accused should be moved into manslaughter's less restrictive and more circumstance-sensitive sentencing regime. ${ }^{35}$ If provocation reduces murder to manslaughter, the judge must consider the circumstances of the provocation in sentencing. The effect of provocation is not exhausted by reclassifying the homicide. ${ }^{36}$

It might seem surprising that provocation is not a defence to attempted murder. It might be asserted as well that if provocation is a defence to murder, it should be a defence to other less serious offences too:

[T] here is no principled reason why provocation should apply only in the case of murder. While provocation has always been seen as an ameliorating influence, softening the harshness of the minimum life imprisonment penalty for murder, it is at the same time a form of societal recognition of human frailties which ought to apply equally to all offences. It is arbitrary in the extreme that an accused who attacks another under provocation may plead the provocation if the other person dies, but not if he or she survives. ${ }^{37}$

Consider, however, that the general punishment for attempted murder is a maximum sentence of life imprisonment. ${ }^{38}$ With the exception of high treason, no offences other than murder have a minimum sentence of life imprisonment. For attempted murder and other offences the sentencing judge has ample scope to exercise discretion based on the circumstances of the offence..$^{39}$ Provocation is not required to pull the offence out of a rigid sentencing structure or to pull the offender's blameworthiness from classification as one of our most serious offences.

Those advocating the abolition of provocation see this linkage between the sentencing for murder and provocation as showing the way to eliminate the defence. If the mandatory minimum sentence for murder were repealed, provocation would lose its purpose and could

R. v. Howe, [1987] 1 A.C. 417 at 433 (H.L.), Lord Hailsham of St. Marylebone.

R. v. Stone, [1999] 2 S.C.R. 290 at para. 237 [Stone].

Ibid. at paras. 236-37.

Canadian Bar Association, Criminal Recodification Task Force, Principles of Criminal Liability: Proposals for a New General Part of the Criminal Code - Report of the Criminal Recodification Task Force (Ottawa: Canadian Bar Association, 1992) at 121, reprinted in François Lareau, "Selected Bibliography on Provocation, Part/Partie I: Provocation - Canadian Law/Droit canadien,” online: François Lareau <http://www.lareau-law.ca/provocation.htm> [CBA, Recodification Task Force]; Canada, Department of Justice, Reforming the General Part of the Criminal Code: A Consultation Paper (Ottawa: Department of Justice Canada, 1994) at 21, online: François Lareau <http://www. lareau-law.ca/Reforming1994E.pdf> [Justice Canada, Reforming the General Part].

Criminal Code, supra note 27, s. 239(1)(b). Section 239 does impose mandatory minimum penalties: four years, if the offence involved the use of a firearm other than a restricted or prohibited firearm (s. 239(1)(a.1)); five years, if the offence involved the use of a restricted or prohibited firearm (s. 239(1)(a)(i)); and seven years, in the case of a second or subsequent offence involving the use of a restricted or prohibited firearm (s. 239(1)(a)(ii)).

"We do not believe that it would serve the interests of justice to extend the application of this complex defence to any crime where the existence of sentencing discretion already makes it possible to reflect the nature and degree of the provocation in the sentence itself”: U.K., The Law Commission, Murder, Manslaughter and Infanticide (Project 6 of the Ninth Programme of Law Reform: Homicide, Law Com No 304) (London: The Stationery Office, 2006) at para. 5.80 [LC, Murder]. 
be repealed too. ${ }^{40}$ Upon conviction for murder (or for whatever description of intentional homicide survives the statutory changes), the circumstances of provocation could be considered in sentencing along with other relevant evidence. Nonetheless, despite its elimination of mandatory minimum sentences for homicide, New South Wales retains the provocation doctrine:

\begin{abstract}
While the defence of provocation is no longer necessary for the purpose of providing judges with a discretion in sentencing for unlawful homicide, the defence remains vitally important in terms of gaining community acceptance of reduced sentences for manslaughter rather than murder. The defence of provocation remains necessary as a means of involving the community, as represented by the jury, in the process of determining the degree of an accused's culpability according to his or her loss of self-control in response to provocation. It also means that people who kill with reduced culpability as a result of a loss of self-control under provocation are not misleadingly and unfairly stigmatised by the label "murderer.",1
\end{abstract}

Assessing whether this judgment is accurate will be a burden of Part III.

\title{
2. RELATIONSHIP WITH THE FAULt ELEMENTS FOR MURDER
}

As indicated by the opening words of s. 232(1), provocation is engaged only if, absent the defence, the accused would be guilty of murder. The actus reus and mens rea must be established and no other affirmative defence must be made out. ${ }^{42}$ Otherwise, the verdict would be acquittal, not a verdict of guilt for manslaughter. Provocation assumes killing and the intent to kill, but finds mitigation in the circumstances immediately preceding and accompanying the intentional killing.

Because the evidence relating to provocation will concern, to a greater or lesser extent, the specific transaction between the accused and victim resulting in the victim's death, the evidence may be relevant not only to provocation but to any other affirmative defences, particularly self-defence, ${ }^{43}$ or to the issue of whether the accused had the intent for murder:

The separate and cumulative effect on intention of alcohol or drug consumption, mental illness or mental disorder, provocation and excessive force used in self-defence must be left with the finder of fact. None of these factors is sufficient in itself to be a defence or partial defence. One of them may have a bearing on whether the accused had the intent for murder.... Even if the words and actions of the deceased did not raise a reasonable doubt in the mind of the trier of fact as to whether the accused had been provoked or that the accused was incapable of forming the requisite intent by reason of consumption of alcohol, the trier of fact

LRCC, Homicide, supra note 25 at 73; National Association of Women and the Law, Stop Excusing Violence Against Women: NAWL's Position Paper on the Defence of Provocation by Andrée Côté, Diana Majury \& Elizabeth Sheehy (Ottawa: National Association of Women and the Law, 2000) at para. 2.5 [NAWL, Provocation].

$41 \quad$ NSW LRC, Report, supra note 12 at para. 2.33 [footnotes omitted].

42 R. v. Parent, 2001 SCC 30, [2001] 1 S.C.R. 761 at para. 6 [Parent]; McDonald, supra note 30 at para. 57; R. v. Tran, 2008 ABCA 209, 432 A.R. 234 at para. 43 [Tran]; R. v. Cameron (1992), 7 O.R. (3d) 545 at 546-47 (C.A.) [Cameron]; Campbell, supra note 30 at 681-82; Eric Colvin \& Sanjeev Anand, Principles of Criminal Law, 3d ed. (Toronto: Thomson Carswell, 2007) at 373.

43 Evidence relating to the character of the victim, whether known or unknown to the accused (depending on the nature of the defence alleged by the accused), could be relevant to self-defence or to provocation: see R. v. Rooney (1994), 126 Nfld. \& P.E.I.R. 17 at para. 100 (P.E.I.S.C.) [Rooney]; R. v. Scopelliti (1981), 34 O.R. (2d) 524 (C.A.). 
was nevertheless still required to consider all those surrounding circumstances in coming to a conclusion as to whether the accused had the requisite intent needed to commit murder. ${ }^{44}$

Given that the accused's actual mental state at the material time is at issue for mens rea offences like murder, the Nealy ${ }^{45}$ approach is an unremarkable application of common sense inference and the general principle that relevant evidence is admissible unless its prejudicial effect exceeds its probative value or it is excluded by an exclusionary or constitutional rule.

Unfortunately, the law relating to permissible uses of evidence of anger has become murky since McLachlin C.J.C.'s decision in Parent. ${ }^{46}$ Parent properly confirms that there is no independent defence of anger or rage. ${ }^{47}$ Evidence of anger or rage may be relevant to a provocation claim. It may - far from having an exculpatory role - be circumstantial evidence tending to establish mens rea, actus reus, or both. In the Walle ${ }^{48}$ case, however, Parent was interpreted to entail that evidence of anger short of provocation could not support inferences negativing the mens rea of murder, either alone or in combination with other evidence. Evidence of anger is irrelevant to the mens rea for murder:

\begin{abstract}
Anger is not a stand-alone defence. It may form part of the defence of provocation, but anger short of provocation and on its own cannot negative intent and reduce murder to manslaughter. It is difficult to see how, if anger alone is an irrelevant consideration to the question of intent, it can become relevant when considered in combination with other factors.
\end{abstract}

After Parent, anger felt by an accused, short of provocation, cannot negative the intent to commit murder. It is an irrelevant factor under s. 229(a) and it is an error of law to consider it, whether alone or in combination with other factors. 49

I agree with (now) Gary Trotter J. and Professor Sanjeev Anand that the Walle case imposes an artificial and unjustifiable limitation on the relevance of evidence of anger. In particular, as they have argued, when the route to proof of mens rea in a murder case runs through s. 229(a)(ii) of the Criminal Code (the accused meant to cause bodily harm that he or she knew was likely to cause death and was reckless whether death ensues), anger would be relevant on the issue of the accused's subjective foresight of death. An angry person could strike a killing blow, but without intending to kill or without thinking that his or her blow would cause death. Because he or she was angry, he or she was not thinking clearly, and he or she may not have foreseen the consequences of his or her act. ${ }^{50}$ Kent Roach, Criminal Law, 4th ed. (Toronto: Irwin Law, 2009) at 373, 375; Stuart, supra note 30 at 579. R. v. Nealy (1986), 30 C.C.C. (3d) 460 (Ont. C.A.) [Nealy]. Supra note 42.

Ibid. at paras. 9-10; Roach, supra note 44 at 374; Stuart, supra note 30 at 560-61. R. v. Walle, 2007 ABCA 333, 417 A.R. 338 [Walle].

Ibid. at paras. 29, 31.

Gary T. Trotter, "Anger, Provocation, and the Intent for Murder: A Comment on R. v. Parent" (2002) 47 McGill L.J. 669 at 685-86; Sanjeev Anand, "A Provocative Perspective on the Influence of Anger on the Mens Rea for Murder: The Alberta Court of Appeal's Interpretation of Parent in Walle" (2008) 54 Crim. L.Q. 27; Colvin \& Anand, supra note 42 at 292-93; Stuart, supra note 30 at 560, n. 595. 


\section{BURDEN OF PROOF}

An accused bears only a tactical burden on the issue of whether or not to raise provocation as a defence. ${ }^{51}$ Consistently with other affirmative defences, for the trial judge to put the defence to the jury, the defence must have an "air of reality” on the evidence. The trial judge must find that there is some evidence bearing on each of the elements of the defence, such that a reasonable jury, properly instructed, could find in favour of the accused. ${ }^{52}$ One complication arises from the language of s. 232(3) of the Criminal Code. Under s. 232(3), the issues of

(a) whether a particular wrongful act or insult amounted to provocation, and

(b) whether the accused was deprived of the power of self-control by the provocation that he alleges he received,

are questions of fact, for the jury. ${ }^{53}$ The trial judge is not entitled to decide whether an act did amount to provocation and to so direct the jury. This would have been the job of the judge under the old categorical approach to provocation. ${ }^{54}$ Section 232(3) does not deny the trial judge's role in determining whether the defence is made available to the jury. The judge still has the threshold responsibility to decide whether the defence has any evidential foundation at all..$^{55}$

Provocation is not required to be established on a balance of probabilities. The accused does not bear a "persuasive" burden. The accused must be convicted of manslaughter rather than murder if the evidence raises a reasonable doubt about whether provocation is available. ${ }^{56}$ The Crown has the burden of negativing provocation — of demonstrating, beyond a reasonable doubt, that some (or all) of the elements of provocation are not established on the evidence. ${ }^{57}$

\section{ELEMENTS OF PROVOCATION}

Provocation has six main elements: ${ }^{58}$

(a) a “wrongful act or an insult”;

$51 \quad$ R. v. Thibert, [1996] 1 S.C.R. 37 at para. 2 [Thibert]; Cameron, supra note 41 at 547; Stuart, ibid. at 477. R. v. Gunning, 2005 SCC 27, [2005] 1 S.C.R. 627 at para. 32; Thibert, ibid. at para. 7; R. v. Humaid
(2006), 81 O.R. (3d) 456 at 476 (C.A.) [Humaid]; Roach, supra note 44 at 297-98; Colvin \& Anand, supra note 42 at 290-91, 372; Stuart, ibid. at 478, 570.

Criminal Code, supra note 27, s. 232(3).

Taylor, supra note 23 at 469.

Thibert, supra note 51 at paras. 6-7.

Hence, in deciding the air of reality issue, the trial judge must consider whether, on the evidence, a reasonable jury could have a reasonable doubt about whether provocation is available. If the accused raises a reasonable doubt respecting provocation, the jury must - not may, despite the occurrence of "may" in s. 232(1) - convict of manslaughter, not murder: Latour v. R., [1951] S.C.R. 19 at 27.

57 Cameron, supra note 42 at 547; Thibert, supra note 51 at para. 2; Roach, supra note 44 at 357; Stuart, supra note 30 at 477.

58 Drawn from the Criminal Code, supra note 27, s. 232. I will set aside the illegal arrest issues dealt with in s. 232(4). 
(b) the wrongful act or insult must have occurred suddenly ("sudden provocation”);

(c) the sudden provocation must have caused the relevant mental state of the accused;

(d) the accused must have acted "in the heat of passion" — the accused must have been "deprived of the power of self-control" by the provocation;

(e) the accused's response to the provocation must have been "sudden" - the accused must have acted "before there was time for his passion to cool"; and

(f) the wrongful act or insult must have been "of such a nature as to be sufficient to deprive an ordinary person of the power of self-control." 59

A deeper assessment of these elements will be provided in Part III. At this point, my intention is only to provide a brief doctrinal exposition to support the discussion to follow.

This exposition is complicated by the Thibert case. ${ }^{60}$ While Thibert confirms standard provocation doctrine (for the most part), its application of that doctrine tends to undermine both the statutory language and the judicial interpretation of provocation. Very generally, the facts of Thibert were these: Mrs. Thibert had an intimate relationship with the deceased, a co-worker. She disclosed this to the accused. About three months later, she left the accused. The next day, she and the accused met. Later that day, the accused phoned her several times at her work. He then put a loaded rifle in his car and drove to intercept Mrs. Thibert while she was away from the office. He did meet her, but she went back to her office. He followed her to the office parking lot. He advised her that he had the gun. The deceased came out of the office and began to lead Mrs. Thibert away. The accused got his gun from his car:

The appellant's evidence was that the deceased began walking towards him, with his hands on Mrs. Thibert's shoulders swinging her back and forth, saying, "You want to shoot me? Go ahead and shoot me." and "Come on big fellow, shoot me. You want to shoot me? Go ahead and shoot me.” At some point, Mrs. Thibert either moved, or was moved aside. The appellant testified that the deceased kept coming towards him, ignoring the appellant's instructions to stay back. The appellant testified that his eyes were closed as he tried to retreat inward and the gun discharged. ${ }^{61}$

This division of the elements of provocation differs from the standard jury instruction, which sets out four elements of provocation and begins with the ordinary person test:

1. There was a wrongful act or insult that was sufficient to deprive an ordinary person of the power of self-control; and

2. When NOA killed NOC s/he had lost the power of self-control as a result of the wrongful act or insult; and

3. The wrongful act or insult was sudden; and

4. NOA's acts that caused NOC's death were committed suddenly and before there was time for his/her passion to cool:

Canadian Judicial Council, Provocation (February 2009) at para. 1, online: Canadian Judicial Council $<$ http://www.cjc-ccm.gc.ca/english/lawyers_en.asp?selMenu=lawyers_provocation_en.asp>.

The standard jury instruction is perfectly acceptable for its purposes, but I have adopted my approach for analytical purposes. 
Justice Cory, writing for a three judge majority of a five judge court, found that on the evidence, the defence of provocation had an air of reality and should have been put to the jury (as in fact it was at trial). ${ }^{62}$ Difficulties arising from Thibert will be mentioned under the appropriate headings.

a. Wrongful Act or Insult

(i) Evidence

There are no special rules relating to the proof of facts characterized as being a wrongful act or insult. Provocation cases are similar to other types of murder cases. ${ }^{63}$ The victim being dead, the evidence is often the accused's testimony, the physical evidence, and any other circumstantial evidence (for example evidence relating to the accused's motives or animus, or (conceivably) similar fact evidence relating to the accused or character evidence relating to the victim); there could be witnesses, or a fortuitous recording of the events.

(ii) Insult

The term "wrongful” modifies "act,” but not "insult”: “an insult is always wrongful.,"64 The Oxford English Dictionary definition of "insult” has been adopted in Canada: "[a]n act, or the action, of attacking or assailing; ... an open and sudden attack or assault without formal preparations; ... injuriously contemptuous speech or behaviour; scornful utterance or action intended to wound self-respect; an affront, indignity." ${ }^{\text {"65 }}$ Recall that, at common law, words (unless they threatened an assault) could not count as provocation. Our law follows the Draft Code and its reasoning: "We are of opinion that cases may be imagined where language would give a provocation greater than any ordinary blow.",66

Legal Status of the Wrongful Act or Insult

Thibert confirmed that "a wrongful act or an insult" need not be an illegal act: "[t]he words or act put forward as provocation need not be words or act which are specifically prohibited by the law. ${ }^{, 67}$ Insults (at least short of blasphemous or defamatory libel ${ }^{68}$ ) are not illegal acts. An act which in fact provokes could be, but need not be, an assault. This "wrongful acts" issue is correlated with the "legal right" issue considered under (vi), below.

\section{Source of the Wrongful Act or Insult}

The wrongful act or insult, generally, must have issued from the victim and not a third party. The defence has been extended to accuseds who mistakenly believed that the victim

Ibid. at para. 31 .

Lee, supra note 9 at 85.

R. v. D.L., 2005 ONCJ 343, 66 W.C.B. (2d) 544 at para. 22 [D.L.]; R. v. Murdoch (1978), 40 C.C.C. (2d) 97 at 103 (Man. C.A.).

The Oxford English Dictionary, 2d ed., s.v. “insult.” See Thibert, supra note 51 at para. 8 (relying on Taylor, supra note 23 at 475).

Taylor, ibid. at 470.

Thibert, supra note 51 at para. 29.

Criminal Code, supra note 27, ss. 296-97. 
was responsible for the provocation, when in fact it was another person.$^{69}$ Chief Justice Duff was of the view that

acts of provocation committed by a third person, which might be sufficient to reduce the offence to manslaughter if the victim had in fact participated in them, may have the same effect where the offence against the victim is committed by the accused under the belief that the victim was a party to those acts, although not implicated in them in fact. ${ }^{70}$

\section{(v) Understanding of the Wrongful Act or Insult}

An accused may have misunderstood or misinterpreted what the victim actually said or did. This mistake would be relevant to the accused's subjective state. This is no capitulation to the accused's point of view, since the jury must assess the alleged provocation to determine whether it was sufficient to deprive an ordinary person of the power of selfcontrol. A problem for the application of that objective test is whether it applies to what was actually said or done or to what the accused believed was intended. The Alberta Court of Appeal took the former approach in Hansford:

[M]istake of fact can be relevant to the objective branch of provocation because it is open to the accused to say that any ordinary person would have misinterpreted the facts which confronted the accused. However, the requirement for normalcy in the objective test must apply, not only to the reaction by an ordinary person to such events but, also to how the ordinary person would have interpreted such events. ${ }^{71}$

The Court of Appeal's approach has been rejected, and the latter view has been adopted by numerous commentators - the nature of the allegedly provocative act or insult should be assessed from the perspective of the accused's understanding of it. ${ }^{72}$ A subjective approach would be consistent with Duff C.J.C.'s just mentioned view of mistake concerning the source of a provocation. Thibert proceeds on the ground that the accused's subjective interpretation of the events governs:

[W]hen the deceased held [the accused's] wife by her shoulders in a proprietary and possessive manner and moved her back and forth in front of him while he taunted the accused to shoot him, a situation was created in which the accused could have believed that the deceased was mocking him and preventing him from his having the private conversation with his wife which was so vitally important to him. ${ }^{73}$

Justice Cory did not consider whether the accused's possible interpretation of the deceased's action was reasonable in the circumstances. Assessing how the ordinary person would react based on what the accused actually understood makes sense, since the nature of what was

K., The Law Commission, Partial Defences to Murder: Final Report (London: The Stationery Office, 2004) at para. 3.15, online: Law Commission <http://www.lawcom.gov.uk/docs/lc290(2).pdf> [LC, Partial Defences]; Roach, supra note 44 at 361; Lee, supra note 9 at 26. R. v. Manchuk (1937), [1938] S.C.R. 18 at 21 [Manchuk]; Justice Canada, Provocation, supra note 3 at 3.

R. v. Hansford (1987), 75 A.R. 86 at para. 8 (C.A.), Hutchinson J. (ad hoc) [Hansford]; Colvin \& Anand, supra note 42 at 377.

$72 \quad$ Allan Manson, Case Comment on R. v. Hansford, (1987) 55 C.R. (3d) 347; LC, Partial Defences, supra note 69 at para. 3.15; Roach, supra note 44 at 361; Lee, supra note 9 at 26.

Thibert, supra note 51 at para. 23. 
understood would govern the provocative effect of the words. The Hansford ${ }^{74}$ objective approach, one must concede, does provide protection against an accused who claims an understanding of words that has no reasonable connection to what was said. Nonetheless, the objective approach is not a necessary protection in these circumstances, since the unreasonableness of the accused's position would be evidence against accepting it.

\section{Not Constituting Provocation}

Wrongful acts or insults do not include acts that the accused incited the victim to do "in order to provide the accused with an excuse for causing death or bodily harm to any human being"75 (whether, it appears, that would be the victim personally or anyone else). Provocation cannot have been manufactured by the accused. ${ }^{76}$ Statutory language prevented this exclusion from applying to the accused in Thibert, even though the entire tragedy was of the accused's making. He followed his wife to work. He brought the gun. He took the gun out of the car. He pointed it in the direction of the deceased. He could therefore have been said to have "incited" the deceased to respond to him. Nevertheless, the evidence did not appear to support the inference that the accused acted as he did "in order to" create an excuse to kill the deceased.

Wrongful acts or insults do not include anything that the victim "had a legal right to do."”7 On a broad reading, persons have a "legal right" to do anything that is not specifically illegal. If that reading were adopted, then only potential criminal or other offences on the part of the victim could support provocation, contrary to the interpretation of "wrongful act or insult." The courts have adopted a narrower reading. For a victim to have had a "legal right" to do the act in question, he or she must have had a specific legal authority to do the act:

In the context of the provocation defence, the phrase "legal right" has been defined as meaning a right which is sanctioned by law as distinct from something which a person may do without incurring legal liability. Thus the defence of provocation is open to someone who is "insulted". The words or act put forward as provocation need not be words or act which are specifically prohibited by the law. It was put in this way in R. v. Galgay, [1972] 2 O.R. 630 (C.A.), by Brooke J.A. (at p. 649):

\footnotetext{
The absence of a remedy against doing or saying something or the absence of a specific legal prohibition in that regard does not mean or imply that there is a legal right to so act. There may be no legal remedy for an insult said or done in private but that is not because of legal right. The section distinguishes legal right from wrongful act or insult and the proviso of the section ought not to be interpreted to license insult or wrongful act done or spoken under the cloak of legal right.
}

This interpretation of "legal right" was adopted in R. v. Haight (1976), 30 C.C.C. (2d) 168 (Ont. C.A.), where, at p. 175, Martin J.A. noted that "[t]he law does not approve of everything which it does not forbid."78

Supra note 71.

Criminal Code, supra note 27, s. 232(3).

Stuart, supra note 30 at 563.

Criminal Code, supra note 27, s. 232(3).

Thibert, supra note 51 at para. 29. 
The authorities are right as a matter of statutory interpretation. Provocation may include an insult. Insulting someone is not an offence. Hence, a person is not prevented by law from insulting another. A person has, in this sense, a legal right to insult another. If that were the sense of "legal right" in the last clause of s. 232(3), s. 232 would be incoherent: a provocation may be an insult (which a person had a legal right to utter), but a provocation could not include an insult (because the person had a legal right to utter it).

Nevertheless, Kent Roach is right that the breadth of potential provocations and the severe limitations of the "legal right" exclusion is unfortunate, especially in the context of violence against women. Claims of provocation could be conceivably mounted on "trivial acts or insults or when women tell men that they are leaving a relationship."79 I will return to this issue below.

\section{b. Suddenness of Wrongful Act or Insult}

The defence turns on "sudden provocation." From the perspective of the accused, the alleged provocation must have been unpredictable, unanticipated, unexpected, a surprise: "the wrongful act or insult must strike upon a mind unprepared for it ... it must make an unexpected impact that takes the understanding by surprise and sets the passions aflame." 80 Suddenness does not require disconnection from history. While the alleged provocation itself must be sudden and unanticipated, its meaning and effect may rely on or be conditioned by the history of the relationship between the accused and the victim. The past colours the present. The sudden provocation may be "the last straw." ${ }^{\text {"1 }}$ History that informs the accused's understanding of the wrongful act or insult is relevant to the accused's subjective state. It is also relevant to the jury's assessment of how the ordinary person would understand the wrongful act or insult.

The Thibert decision is vulnerable on the suddenness ground. Perhaps because he was distracted by the history of the relationship between the accused and the deceased, Cory J. did not assess whether the evidence supported a finding of "sudden" provocation. Again, the accused manufactured the chain of circumstances. He followed his wife back to her work, where he knew the deceased also worked. The accused brought out his gun. The deceased did not spring out of the office and surprise the accused. The deceased apparently moved Mrs. Thibert back and forth, taunted the accused several times, and moved towards the accused. The accused told him to stay back. The accused "tried to retreat inward." 82 No sudden impact is discernable in this chain of events, although, in fairness, the events unrolled quickly.

Roach, supra note 44 at 359; Colvin \& Anand, supra note 42 at 376 . I note that Cory J. did remark, without elaboration, that "[o]bviously, events leading to the break-up of the marriage can never warrant taking the life of another. Affairs cannot justify murder”: Thibert, supra note 51 at para. 22.

$80 \quad$ R. v. Tripodi, [1955] S.C.R. 438 at 443; Thibert, ibid. at para. 20; McDonald, supra note 30 at para. 59; R. v. Faid, [1983] 1 S.C.R. 265 at 276 [Faid]; Tran, supra note 42 at paras. 18, 66; R. v. Lei (1997), 120 C.C.C. (3d) 441 at 454 (Man. C.A.); D.L., supra note 64 at para. 23; Roach, ibid. at 361.

81 Thibert, ibid., quoting Glanville Williams, Textbook of Criminal Law, 2d ed. (London: Stevens \& Sons, 1983) at 530; R. v. Daniels (1983), 47 A.R. 149 at 154-55 (N.W.T. C.A.) [Daniels]. Thibert, ibid. at para. 48. 


\title{
c. Sudden Provocation as Cause
}

The accused must have "acted on" the wrongful act or insult. ${ }^{83}$ The alleged provocation cannot have been merely correlated with the attack, merely a pretext for the attack, or merely a source of motive for the attack. The alleged provocation must have induced the accused's mental condition of lack of self-control. ${ }^{84} \mathrm{~A}$ difficulty for an accused who has a history with a victim may be that if (for example) the victim had insulted the accused many times before, the accused may simply have formed the intention to kill earlier and followed through on that intention, without the influence of the last, allegedly provocative act. The evidence would have to support the inference (which the jury would have to draw) that immediately before the wrongful act or insult, despite the past insults and regardless of what the accused might have thought or intended in the past, the accused did not have the intent to kill the victim. That intent only arose after and through the effects of the alleged provocation.

\section{d. Acting "in the Heat of Passion"}

The accused must have been "deprived of the power of self-control" by the provocation. ${ }^{85}$ It must have induced a "passion" that produced the intention to kill the victim and prevented the accused from choosing not to kill the victim. ${ }^{86} \mathrm{~A}$ "passion" is a strong emotion. While statute does not restrict the passion that produces the effects on the accused, practically, it would be anger or fear. As indicated above, the experience of anger (and, by extension, any strong emotion) is not, by itself, a complete or partial defence. ${ }^{87}$ The emotion must degrade, diminish, or significantly impair the usual ability to choose. An accused who "gives in" to extreme anger or has failed to exercise self-control has not been provoked within the meaning of the Criminal Code - he or she chose or allowed himself or herself to pursue ends set by emotion:

\begin{abstract}
All who kill in anger might be described as having reached a state where reason has been temporarily eclipsed by anger as a guiding force influencing his or her action. Section 232 of the Code however, does not excuse those who lose control and kill, it excuses those who, following the language of s. 232(2), have been deprived of the power of self-control. In other words, for reasons understandable to the ordinary person, they have been unable to control themselves. ${ }^{88}$
\end{abstract}

On the issue of the accused's subjective or actual reaction to the alleged provocation, evidence relating to individual characteristics of the accused is admissible, such as the accused's race, religion, sexual orientation, or intoxication. ${ }^{89}$

An important issue in Thibert, not assessed by Cory J., was whether the accused was in fact provoked, in the sense of having been deprived of self-control. We could accept that, in

Criminal Code, supra note 27, s. 232(2).

Faid, supra note 80 at 276; Daniels, supra note 81 at 547-48.

Criminal Code, supra note 27, s. 232(3)(b).

Ibid., ss. 232(1)-(2).

Parent, supra note 42 at para. 10.

R. v. Gibson, 2001 BCCA 297, 90 B.C.L.R. (3d) 247 at para. 79; R. v. Bicknell, 2003 BCSC 1522, 59

W.C.B. (2d) 425 at para. 134; D.L., supra note 64 at para. 24. Canadian law at least avoids statutory ambiguity on the issue of whether provocation relates to a failure to exercise self-control or the inability to exercise self-control, turning on the latter: LC, Partial Defences, supra note 69 at para. 3.28. Hill, supra note 4 at para. 41; Stuart, supra note 30 at 569. 
all the circumstances, the deceased's taunting of the accused could have been understood by the accused as an insult. As recounted by Cory J., though, the evidence does not indicate that the accused was deprived of self-control:

The deceased continued to approach the appellant, proceeding as fast as he could. In turn, the appellant kept backing up and told the deceased to "stay back", but the deceased continued to approach him. The appellant testified that he remembered wanting to scream because the deceased would not stop coming towards him. The appellant's eyes were tightly closed when he fired the gun. ${ }^{90}$

This narrative indicates that the accused had self-control. He backed up. He told the accused to stop. He did not lose control — he shut his eyes. He fired the gun. There is no indication of overwhelming emotion and no indication that he had a nearly irresistible impulse to kill the deceased. Nevertheless, in all the circumstances, inferences might have been drawn that the accused did not intend to kill the deceased and that he did not mean to cause bodily harm that he knew was likely to cause death. If his eyes were indeed shut, he may not even have been aiming at the deceased. Thibert could have been a Nealy case. It does not appear to have been a provocation case.

\section{e. Suddenness of Accused's Response}

The accused must have acted "before there was time for his passion to cool."91 The mental state caused by the act or words must have persisted to the time of killing. If, on the evidence, the accused reasserted self-control, even after a wildly provocative act, the relevant effect of the provocation terminated and the defence would no longer be available. ${ }^{92}$

\section{f. Impact of the Wrongful Act or Insult on the Ordinary Person}

The jury must determine whether the wrongful act or insult would be "sufficient to deprive an ordinary person of the power of self-control."93 The ordinary person test is an "objective" test, much like the "reasonable person" or "reasonableness" tests found throughout the law. In effect, the accused's actions are being judged from the perspective of his or her community, as embodied in the jury: "The open-ended nature of the reasonableness requirement is designed to allow community input on matters involving difficult value judgments and provide greater flexibility and fairness in legal decision making than is permitted by strict rules." 94 Note that the jury is not required to consider the proportionality or reasonableness of the accused's actual acts in responding to the provocation. The accused's acts could not be reasonable or proportional, since the accused killed the victim when no other mitigating circumstances applied. The issue is only whether the ordinary

\footnotetext{
$90 \quad$ Thibert, supra note 51 at para. 26.

$91 \quad$ Criminal Code, supra note 27, s. 232(2).

$92 \quad$ Tran, supra note 42 at para. 72. See R. v. Willis, 2007 ONCA 365, 224 O.A.C. 159 at para. 25: More importantly, there is no air of reality that the accused was deprived of self control or that she acted "on the sudden". To the contrary, during her telephone discussion with the deceased's lawyer, she modulated her voice pretending to be co-operative. She then strode back to her truck with the baby, deposited the baby safely in the truck, retrieved the gun and shot the deceased eight times. These actions cannot be characterized as acting "on the sudden" or in the heat of passion and "before there was time for her passion to cool." 
person would have lost control, as did the accused. ${ }^{95}$ The jury could still consider the accused's conduct, but only as evidence on the issue of whether the accused was in fact provoked.

A problem besetting the application of the ordinary person test is the scope of the set of characteristics that the ordinary person should share with the accused. The test must be kept objective, so that the accused is judged by community standards and not by the accused's own standards. The ordinary person, then, cannot share all of the accused's characteristics. The House of Lords decision in Camplin provides a crucial distinction between the cognitive and volitional elements of the ordinary person test that must be applied by the jury. ${ }^{96}$ Cognitively, the jury must be put in a position to know what it was that the accused was responding to. The ordinary person must be put in the circumstances of the accused so it can determine the ordinary person's reaction. The events must be given the meaning or significance that they had for the accused. Justice Wilson made this point in dissent in Hill: "an insulting remark or gesture has to be placed in context before the extent of its provocativeness can be realistically assessed." 97 The jury should receive evidence of "any general characteristics relevant to the provocation in question," 98 so that the ordinary person may be "tested against all of the events which put pressure on the accused," including relevant past events and interactions with the victim. ${ }^{99}$ Volitionally, the ordinary person sets the standard of firmness or the threshold of weakness by which the accused is judged. That standard cannot be subjectivized by the accused's personal characteristics. Any personality or personal traits particular to the accused that would make him or her less able to resist or more inclined to fall under the sway of his or her emotions should be excluded from consideration. The ordinary person can be neither exceptionally excitable nor exceptionally passive, and cannot be intoxicated. ${ }^{100}$ Under current jurisprudence, the ordinary person should be conceived to be of the same sex and age as the accused, since these features "do not detract from a person's characterization as ordinary."101 The age inclusion is a concession to the fact that self-control is a function of maturity. It is a small reflection in the common law of the distinction that we draw between young and adult offenders.

Thibert stumbles badly on the ordinary person test, eliding the cognitive/volitional distinction and failing to properly assess the evidence relating to the cognitive element. ${ }^{102}$ Justice Cory wrote as follows:

R. v. Carpenter (1993), 83 C.C.C. (3d) 193 at 197 (Ont. C.A.); Roach, supra note 44 at 371; Lee, ibid. at 262.

Camplin, supra note 4 at 686, 694-95; Roach, ibid. at 366; Colvin \& Anand, supra note 42 at 382-83. Hill, supra note 4 at para. 69.

Ibid. at para. 35; Thibert, supra note 51 at para. 14.

Daniels, supra note 81 at 158; R. v. Conway (1985), 17 C.C.C. (3d) 481 at 487 (Ont. C.A.); Thibert, ibid. at paras. 16, 21.

列 only modest coaxing is that, in conducting the evaluation of the reasonableness of the accused's conduct, no account should be given to personality traits that would diminish reasonable standards of responsible behaviour”: David M. Paciocco, “Applying the Law of Self-Defence” (2007) 12 Can. Crim. L. Rev. 25 at $40-41$.

101 Hill, ibid. at para. 35.

102 Edward M. Hyland, “R. v. Thibert: Are There Any Ordinary People Left?” (1996-97) 28 Ottawa L. Rev. 145 at 157. 
In this case, it is appropriate to take into account the history of the relationship between the accused and the deceased. The accused's wife had, on a prior occasion, planned to leave him for the deceased but he had managed to convince her to return to him. He hoped to accomplish the same result when his wife left him for the deceased on this second occasion. At the time of the shooting he was distraught and had been without sleep for some 34 hours. When he turned into the parking lot of his wife's employer he still wished to talk to her in private. Later, when the deceased held his wife by her shoulders in a proprietary and possessive manner and moved her back and forth in front of him while he taunted the accused to shoot him, a situation was created in which the accused could have believed that the deceased was mocking him and preventing him from his having the private conversation with his wife which was so vitally important to him.

Taking into account the past history between the deceased and the accused, a jury could find the actions of the deceased to be taunting and insulting. It might be found that, under the same circumstances, an ordinary person who was a married man, faced with the break-up of his marriage, would have been provoked by the actions of the deceased so as to cause him to lose his power of self-control. There was some evidence, therefore, that would satisfy the objective element of the test. ${ }^{103}$

The lack of sleep could not be relevant to the volitional element of the test, since if the ordinary person is not intoxicated, the ordinary person is not sleep deprived. The facts of marriage and marriage breakup are relevant — if there had been no intimate relationship between the accused and Mrs. Thibert, none of the events would have transpired. These facts are relevant, though, only to the cognitive issue. Self-control does not vary with marital status. One might concede that the fact that the accused had a strong desire to talk to his wife was relevant to the cognitive issue - that desire led to the accused being where he was, and the deceased did frustrate that desire. But the fact that the accused had a strong desire to talk to Mrs. Thibert was irrelevant to the self-control issue. Self-control does not vary with particular desires. The paragraphs in questions confuse too much. While Thibert is authority, it is not good law.

One might think that the trial judge would have a duty to instruct the jury respecting the characteristics that the ordinary person should be conceived to have and not have. A surprising feature of Hill, ${ }^{104}$ which has never been reassessed by the Supreme Court, is that it does not require judges to provide particularized instructions respecting the relevant characteristics of the ordinary person:

I should also add that my conclusion that certain attributes can be ascribed to the ordinary person is not meant to suggest that a trial judge must in each case tell the jury what specific attributes it is to ascribe to the ordinary person. The point I wish to emphasize is simply that in applying their common sense to the factual determination of the objective test, jury members will quite naturally and properly ascribe certain characteristics to the "ordinary person”.

Thibert, supra note 51 at paras. 23-24. I might observe that on this account, the deceased had an important but indirect relationship with the accused — he was the third point of the triangle, but did not interact directly with the accused. If this evidence is relevant to provocation as "history" evidence, its probative value on the issue of losing control is low. Supra note 4. 
The trial judge did not err in failing to specify that the ordinary person, for the purposes of the objective test of provocation, is to be deemed to be of the same age and sex as the accused. Although this type of instruction may be helpful in clarifying the application of the ordinary person standard, I do not think it wise or necessary to make this a mandatory component of all jury charges on provocation. Whenever possible, we should retain simplicity in charges to the jury and have confidence that the words of the Criminal Code will provide sufficient guidance to the jury. ${ }^{105}$

I will end this Part with two comments on the elements of the partial defence of provocation. First, despite the inclusion of an objective assessment of the accused's conduct, the provocation rules have not been found to be contrary to the Canadian Charter of Rights and Freedoms, ${ }^{106}$ as violating an accused's rights to fundamental justice: "Section 232 does not impose liability where subjective fault does not exist, but reduces the liability even when that fault exists." ${ }^{107}$ The provocation rules do not permit the conviction of individuals without a requisite level of blameworthiness. The accuseds for whom provocation is available have intentionally killed their victims.

Second, the provocation provisions have been criticized as being excessively complex, too complex for a jury to understand and apply. Specifically, the argument has been made that, in applying the ordinary person test, juries would not be able to distinguish evidence relevant to the cognitive element from evidence relevant to the volitional element. ${ }^{108}$ This is not a compelling argument — or it is too compelling. The application of many criminal law rules is complex. Self-defence, necessity, and duress all have subjective and objective elements. Juries are often asked to consider evidence in relation to one issue, but not to consider it in relation to another - for example, respecting the use of an accused's criminal record, evidence admissible against one co-accused but not another, or similar fact evidence admissible on a specific issue but not as evidence of the accused's propensity to commit crimes. Our belief that juries - and judges, since legal training does not augment common sense - can make the relevant distinctions is what I would call an element of our constitutional faith. Chief Justice Dickson wrote as follows:

In my view, it would be quite wrong to make too much of the risk that the jury might use the evidence for an improper purpose. This line of thinking could seriously undermine the entire jury system. The very strength of the jury is that the ultimate issue of guilt or innocence is determined by a group of ordinary citizens who are not legal specialists and who bring to the legal process a healthy measure of common sense. The jury is, of course, bound to follow the law as it is explained by the trial judge. Jury directions are often long and difficult, but the experience of trial judges is that juries do perform their duty according to the law. We should regard with grave suspicion arguments which assert that depriving the jury of all relevant information is preferable to giving them everything, with a careful explanation as to any limitations on the use to which they may put that information. So long as the jury is given a clear instruction as to how it may and how it may not use evidence of prior convictions put to an accused on cross-examination, it can be argued that the risk of improper use is outweighed by the much more serious risk of error should the jury be forced to decide the issue in the dark.

Ibid. at paras. 37, 40.

Part I of the Constitution Act, 1982, being Schedule B to the Canada Act 1982 (U.K.), 1982, c. 11 [Charter]

Cameron, supra note 42 at para. 6; Roach, supra note 44 at 372.

LRCC, Homicide, supra note 25 at 73; NSW LRC, Report, supra note 12 at para. 2.56. 
It is of course, entirely possible to construct an argument disputing the theory of trial by jury. Juries are capable of egregious mistakes and they may at times seem to be ill-adapted to the exigencies of an increasingly complicated and refined criminal law. But until the paradigm is altered by Parliament, the Court should not be heard to call into question the capacity of juries to do the job assigned to them. The ramifications of any such statement could be enormous. Moreover, the fundamental right to a jury trial has recently been underscored by s. 11(f) of the Charter. If that right is so important, it is logically incoherent to hold that juries are incapable of following the explicit instructions of a judge. Yet it is just this holding that is urged upon this Court by the appellant, for it is only this holding that can justify the conclusion that when s. 12(1) of the Canada Evidence Act is employed against an accused, the section infringes the accused's right to a "fair hearing".

We should maintain our strong faith in juries which have, in the words of Sir William Holdsworth, "for some hundreds of years been constantly bringing the rules of law to the touchstone of contemporary common sense" (Holdsworth, A History of English Law (7th ed. 1956), vol. I, at p. 349). ${ }^{109}$

On the other hand, if the complexity criticism of the provocation provisions is valid, it is an equally valid criticism of great swaths of our law. Where would we begin, and where would we end?

\section{The Culpability of A Provoked Accused}

The previous Part provided an overview of the provocation defence. I now turn to its assessment. One might wonder why a provoked accused deserves any penal solicitude. Why should we think that acting in hot blood, or less figuratively, acting out in homicidal rage, requires any sort of mitigation of penal label or sentencing? Why should any individual with an intention to kill arising in any circumstances not supporting an outright acquittal be judged to be less morally culpable than a murderer?

\section{A. JUSTIFICATION OR EXCUSE? ${ }^{110}$}

The orientation of the response to these questions is important. On the one hand, one might seek to conceptualize provocation as a (partial) justification. On the other hand, one might seek to conceptualize provocation as a (partial) excuse. If provocation were a justification, a provoked act would be the right thing to do in the circumstances, or at least (given that provocation does not completely exonerate) more right than wrong. If provocation were a justification, the law would, in effect, be saying that homicidal violence was right whether the victim was an abused spouse, a person who made a homosexual advance, or someone who insulted the accused in a bar. Provocation would blame victims. ${ }^{111}$ If that were provocation's meaning and effect, it would not belong in our criminal law. In contrast, if provocation were an excuse, no claim of right would be at issue. Instead, the accused would

R. v. Corbett, [1988] 1 S.C.R. 670 at paras. 39, 40, 42 [emphasis in original].

See Roach, supra note 44 at 293-94; Colvin \& Anand, supra note 42 at 286; Lee, supra note 9 at 227; George Mousourakis, "Reason, Passion and Self-Control: Understanding the Moral Basis of the Provocation Defence" (2007) 38 R.D.U.S. 215 at 218. Justice Canada, Provocation, supra note 3 at 8; Mison, supra note 8 at 146-47. 
appeal to the mental state in which he or she killed and to the weakness shared with others to mitigate the stigma and punishment he or she deserves. If that were provocation's meaning and effect, it could be consistent with the effort of our criminal law to calibrate stigma and punishment to the moral blameworthiness of offenders (assuming that provocation does pick out a distinct level of culpability).

We distinguish between justifications and excuses in ordinary language. ${ }^{112}$ A justification involves the acceptance of responsibility, but the denial that what was done was wrong. ${ }^{113}$ Justifications have four main features. First, justifications operate in a binary, apply/do not apply fashion. If an act is justified, it is right. If it is not justified, it is wrong. An act that is justified may be supported by evidence of varying strengths, but justification itself does not fall along a continuum of not-justified, partially justified, and fully justified. ${ }^{114}$ Second, justification involves a congruence or relationship of proportionality between the accused's act and the relevant circumstances. Self-defence can be taken as an example of a justification (regardless of any legal characterization, although the Criminal Code itself labels it a justification). ${ }^{115}$ Self-defence applies in the face of an unprovoked assault. Under s. 34(1), an accused who does not intend to kill may be justified in using proportionate force to defend himself or herself. Under s. 34(2), an accused may be justified in using deadly force if he or she believed, on reasonable grounds, that he or she would be killed or would suffer grievous bodily harm, and he or she could not otherwise preserve himself. The accused's acts are measured by the threat the accused faces. An assault may be met by proportional force; a deadly assault may be met by deadly force. While we might not (or might) assert that a victim of an accused acting in self-defence deserved to die, the victim's actions - at least as regards the accused or those under the protection of the accused ${ }^{116}$ — had the effect of suspending or subordinating the victim's interests in not being a target of physical force. Third, justifications use means that are ordinarily illegal or discouraged to protect ends that are acceptable or socially endorsed or promoted. In self-defence, the right to life and physical security is protected through physical violence. Fourth, the ordinarily prohibited means used by justifications are permitted because they are necessary, in the sense that no other legal means of protecting the interests in question were practically available. Justifications involve "moral involuntariness.” The accused was conscious and had an operating mind. The accused made a choice to violate the law. In the circumstances, though, there was no other way to preserve the accused's interests. ${ }^{117}$

George Fletcher and Stephen Coughlan have asserted that justifications affect a "matrix of legal relationships," such that if an act is justified, third parties are obligated to recognize the rightfulness of the accused's actions. ${ }^{118}$ They are asserting that justifications have some

J.L. Austin, “A Plea for Excuses” in J.O. Urmson \& G.J. Warnock, eds., Philosophical Papers, 2d ed. (London: Oxford University Press, 1976) 175 at 177 . Stuart does evince some skepticism about the utility of the distinction: Stuart, supra note 30 at 470-71.

113 Austin, ibid. at 176.

114 Suzanne Uniacke, Permissible Killing: The Self-Defence Justification of Homicide (Cambridge: Cambridge University Press, 1994) at 13.

Criminal Code, supra note 27, ss. 34(1)-(2); Uniacke, ibid. at 34-35.

Criminal Code, ibid., s. 37.

George Fletcher, Rethinking Criminal Law (Boston: Little, Brown, 1978) at 802-804. On the issue of "moral involuntariness" as a legal concept, see R. v. Ruzic, 2001 SCC 24, [2001] 1 S.C.R. 687 at paras. 45-47 [Ruzic].

118 Fletcher, ibid. at 762; Stephen G. Coughlan, "Duress, Necessity, Self-Defence and Provocation: Implications of Radical Change?” (2002) 7 Can. Crim. L. Rev. 147 at 157. 
sort of in rem effect or, in Wesley Newcomb Hohfeld's terminology, a multital effect. ${ }^{119}$ This matrix claim seems to be based on two confusions. First, if an act is justified or right, it does not necessarily establish a "right" in the sense of a legal entitlement to which others' duties are correlated. A justification in the criminal context is more in the nature of an immunity, the opposite of a liability, to which the state's lack of entitlement to punish is correlated. ${ }^{120}$ Second, a justification operates in personam or establishes only, in Hohfeldt's terminology, paucital relations. ${ }^{121}$ A justification is made out in particular circumstances, such as a particular unprovoked assault by the victim. Recognizing self-defence does not entail that the accused would be exempt from criminal liability with respect to uses of force against any other individuals. If some third parties intervened to try to stop an accused from responding with deadly force, assuming that the third parties were not demonstrating any homicidal intentions, the accused would not be justified in killing them. We will not take the "matrix effect” to be part of justifications.

An excuse involves an admission that what was done was wrong, but a denial of full responsibility. ${ }^{122}$ Excuses have four main features. First, excuses do not operate in a binary, apply/do not apply fashion. An excuse may provide no, partial, or even full exoneration. Excuses operate on a continuum. As J.L. Austin notes, "few excuses get us out of it completely: the average excuse, in a poor situation, gets us only out of the fire into the frying pan."123 Second, excuses do not necessarily involve any congruence or relationship of proportionality between the accused's act and the circumstances. The focus of an excuse is on the personal: "Because of my personal features X, Y, or Z, I should be treated leniently" (such as, age, intoxication, foolishness, previous good record/first time offence). Background and context may be important, but what is critical for an excuse is the reason for the accused's personal failure to behave correctly. Third, excuses do not necessarily promote any socially endorsed ends ('I’m sorry that my assignment was turned in late — I accidentally erased my final draft; I got caught in traffic; I am addicted to computer games and wasted all my time”). A purported excuse, of course, may be unacceptable. While justifications draw moral support from the end sought to be achieved, excuses draw moral support, or better, secure moral recognition because the failure they embody is one that is understood and tolerable: "these things happen.” Fourth, like justifications, some excuses might rely on moral involuntariness: in the circumstances, there was nothing else that the accused could have done.

Provocation does not fit easily into the categories of justification or excuse in ordinary language. Austin observes that "when we plead ... provocation, there is genuine uncertainty or ambiguity as to what we mean - is he partly responsible, because he roused a violent impulse or passion in me, so that it wasn't truly or merely me acting 'of my own accord' (excuse)? Or is it rather that, he having done me such injury, I was entitled to retaliate (justification)?” 124 When we do use provocation reasoning in our everyday moral lives,

Wesley Newcomb Hohfeld, “Fundamental Legal Conceptions as Applied in Judicial Reasoning” (1917) 26 Yale L.J. 710 at 712 [Hohfeld, "Fundamental Legal Conceptions II”].

Wesley Newcomb Hohfeld, "Some Fundamental Legal Conceptions as Applied in Judicial Reasoning" (1913) 23 Yale L.J. 16 at 55.

Hohfeld, “Fundamental Legal Conceptions II,” supra note 119 at 718.

Austin, supra note 112 at 176.

Ibid. at 177 [emphasis in original]; Uniacke, supra note 114 at 24.

Austin, ibid. [emphasis in original]. 
provocation is often more in the nature of justification than excuse. If we are called to account for a wrong against another and seek to rely on provocation, we would typically point to what the victim did: "But he did X to me.” The morally salient circumstance was the victim's action that elicited my response, and my response was morally right because it was an appropriate response to the provocation. In ordinary usage, the exoneration offered by provocation tends to be proportional to the blameworthiness of the provocation ("he had it coming"). The term "provocation" is often used in geopolitical contexts, as when one country parks missiles on the border with its neighbour. In these contexts, provocation even more strongly has the character of a justification. Because of the provocation through missileparking, the neighbour would claim to be right to retaliate, even pre-emptively. Provocation, in political contexts, seems to operate as a complete — not partial — defence.

The defence of provocation, however, at least in its modern form, is better understood as an excuse than as a justification. ${ }^{125}$ Successful invocation of provocation does not result in an acquittal, but in the classification of the culpable homicide as manslaughter. It reclassifies, but it does not forgive. It accepts that the act was wrong, but seeks mitigation. A complicating factor for provocation is that it has both binary and non-binary functions. It has a binary function (like a justification) in that provocation is either made out or it is not. The offence is either murder or manslaughter. It has a non-binary function (like an excuse) in that it opens up the sentencing range for the accused, and the circumstances of the provocation (which should be considered in sentencing) will, to a greater or lesser extent, reduce the punishment to something less than life imprisonment.

Like in the case of an excuse, the primary focus of the defence is on the accused and his or her error. As indicated above, the defence has consistently been supported as a concession to human weakness. ${ }^{126}$ Unlike a justification, the defence does not require a correlation of proportionality between the external precipitating circumstances and the accused's response. The defence operates not because "the victim deserved it," but because the accused lost his or her self-control. The homicide itself cannot be deemed right, since the doctrine judges only the accused's loss of self-control, not the killing, which cannot be justified. The reasonableness or proportionality of the accused's conduct is not at issue. It is true, though, that to the degree that the accused's conduct was in fact a proportional response to the victim's acts, the provocation will have a larger mitigating effect on the accused's sentence. Unlike self-defence (or, for that matter, necessity), provocation does not draw moral force from the promotion of valid ends through prohibited means. From the perspective of the accused, the provoked act may indeed serve and support the accused's interests, whatever they may be. From the perspective of the ordinary person, the accused's reason for acting is less important than the reasons for the loss of self-control. Provocation does involve a type of "moral involuntariness," in the manner of some justifications and excuses. As will be discussed below, the moral involuntariness operating in provocation is distinguishable from other varieties, if only because it does not involve a conscious choice by an accused to use illegal means to secure his or her ends.

125 Joshua Dressler, "Why Keep the Provocation Defense?: Some Reflections on a Difficult Subject” (2002) 86 Minn. L. Rev. 959 at 971; Lee, supra note 9 at 227; Victoria Nourse, "Passion’s Progress: Modern Law Reform and the Provocation Defense” (1997) 106 Yale L.J. 1331 at 1394; Uniacke, supra note 114 at $10,14,51$.

$126 \quad$ Hill, supra note 4 at para. 14; Thibert, supra note 51 at paras. 4, 22; Campbell, supra note 30 at 682; D.L., supra note 64 at para. 20. 
As a matter of law, it is likely that the courts, following Perka, would categorize provocation as an excuse (or, more precisely, a partial excuse). ${ }^{127}$ In Perka, the nature and criteria for the defence of necessity were at issue. Necessity is a stronger defence than provocation, since it wholly exonerates. The defence requires an inquiry into the proportionality between the necessitous circumstances and the accused's response. But necessity was classified as an excuse. Provocation has no higher claim to be classified as a justification. Law reform agencies have taken the view that provocation should be characterized as an excuse. ${ }^{128}$

Provocation is sometimes criticized for the misplaced "compassion" it extends to murderers, as if the availability of provocation means that accused are the real victims victims, that is, of deceased victims' provocations. ${ }^{129}$ Some defences may involve characterizing the accused as the true victim, ${ }^{130}$ and sometimes provoked accused are indeed true victims (an abused spouse who kills, a mother who kills the man who sexually assaulted her daughter) and deserve compassion. But a claim for compassion is not an essential feature of provocation. We no more show compassion by classifying a culpable homicide as manslaughter based on the defence of provocation than we do by classifying a homicide as manslaughter based on an accused's culpable negligence absent mens rea. Provocation concerns the calibration of stigma and penalty to an act, not the eliciting of an emotional response in favour of an accused.

\section{B. IN WHAT LiES THE EXCUSE? WRONGFUL ACT OR INSULT}

If provocation is an excuse, why is it an excuse? The answer has three parts reflected in the structure of the defence - a wrongful act or insult, a subjective response by the accused, and an objective assessment by the jury. The wrongful act or insult element of the defence has two aspects of its own: (i) what is the role of the wrongful act or insult?; and (ii) what should count as a wrongful act or insult?

\section{ROLE OF THE WRONGFUl ACT OR INSUlT}

A provoked accused does not simply lose self-control spontaneously. The loss of selfcontrol is elicited by an external act that the accused did not incite. As with defences like necessity and duress, the provoked accused finds himself or herself in unexpected circumstances, for which the accused is not responsible, and reacts within those circumstances. The "suddenness" requirement reinforces the unexpected nature of the external act. The unexpectedness of the external act has, in itself, a tendency to excuse. If we find ourselves in unexpected circumstances, it can be easier to do the wrong thing. An offence committed on the sudden, in the face of a striking and emotionally charged event,

Perka v. R., [1984] 2 S.C.R. 232 [Perka]. "[P]rovocation ... neither justifies nor excuses the act of homicide. But the law accounts the act and the violent feelings which prompted it less blameable because of the passion aroused by the provocation”: Manchuk, supra note 70 at 19 . NSW LRC, Report, supra note 12 at para. 2.21.

NAWL, Provocation, supra note 40 at para. 2.1.

See Alan M. Dershowitz, “The Abuse Excuse: Zacarias Moussaoui’s lawyers float the 'Impoverished French Muslim Syndrome'” Slate Magazine (20 April 2006), online: Slate Magazine <http://www. slate.com/id/2140262/>; see generally Alan M. Dershowitz, The Abuse Excuse and Other Cop-outs, Sob Stories and Evasions of Responsibility (Boston: Little, Brown, 1994). 
would tend to be less blameworthy than an offence planned and executed in predicted circumstances.

The external act is a "but for" cause of the violent act. ${ }^{131}$ Legislation requires that the act be the "cause" of the loss of the power of self-control. The accused would not have reacted as he did, absent the event. If the accused would have acted in the same way, regardless of the event, he or she was not provoked and should not be excused. Just because the external event was a "but for" cause or cause-in-fact of the accused's emotional reaction, the victim does not necessarily bear any contributory moral responsibility for the accused's reaction. The victim may bear some personal responsibility — for example, if the victim intentionally made a vicious and unprovoked insult designed to wound the accused. The question of the victim's blameworthiness, if any, is separate from the issue of the accused's blameworthiness. The provocation assessment focuses on the accused's reaction to the external act.

For the external act to have any significant causal effect, the accused must have a role in the constitution of the provocation. The wrongful act or insult does not have to have a purely physical link to an accused's reaction, as if on exposure to some stimulus the accused unthinkingly responded. ${ }^{132}$ A provocation exists within the domain of human conduct. For it to have any effect on the accused, it must not only exist physically, but a meaning must be attributed to it by the accused. If all that occur are sounds, no "insult” is made. If words are understood as a joke, no insult is taken. If words are insulting within a cultural tradition, but the target of the insult is not a member of and does not know about that cultural tradition, no insult is taken. The accused's understanding and the fixing of the provocative act with meaning must occur as a precondition to the accused's reaction. Moreover, provocation does not occur until the accused reacts emotionally to the external act. The external act must be embraced within the subjective for it to function as provocation.

It has been said that "[t]he defence of provocation is ... founded on the idea that the victim has 'caused' the murderer to lose his self-control." 133 The external act by the victim is, admittedly, a cause-in-fact of the provocation. The victim, though, is not causally responsible for the provocation. Provocation is the result of the accused's interpretation and reaction to the events, and the victim controls neither process.

\section{WhAT COUNTS AS A WRONGFUL ACT OR INSULT?}

Provocation is not available if an accused has a strongly adverse emotional reaction to an utterly inoffensive act. Killers are not entitled to pick the acts that will count as provocative. Only "wrongful acts or insults” can support provocation. Provocation would be rotten in its moral foundations if it extended mitigation to accused based on acts that could not defensibly be regarded as wrongful acts or insults.

Williams, supra note 81 at 379.

Dressler, supra note 125 at 971-72. The "furor brevis" must be preceded by a judgment of wrongdoing: Horder, supra note 3 at 80, 106. Horder's view is correct - the accused does not merely (passively) react to an event, but makes a moral or evaluative judgment that he or she was wronged (at 120, 138). NAWL, Provocation, supra note 40 at para. 1.1. 
Must the characterization of the wrongful act or insult lie only in the eye of the accused beholder or may some limits be imposed on the types of acts or words that could count as "wrongful acts" or "insults”? As pointed out above, the lack of criteria for wrongful acts and insults seems to allow trivial insults — or instances of women exercising their rights to leave their husbands or boyfriends - to support provocation claims. The ordinary person test plays a critical role in screening out unmeritorious defences. The jury is to decide whether or not a particular wrongful act or insult amounted to provocation. One might ask, however, why better protections should not be in place to ensure that illegitimate defences are not put to the jury. Recall that the common law categorical approach did set out legal tests to determine the sets of circumstances that could count as provocation. Even in the case of adultery, the common law did not find provocation in the termination of relationships, but only in witnessing acts of adultery. ${ }^{134}$

The topics of insults are infinitely variable and will depend in great measure on individuals, their personal characteristics, and their relationships. Imposing restrictions on what might constitute an insult would risk ruling out some legitimately provocative insults. It has been suggested that "non-violent sexual advances by either gender" should be excluded from wrongful acts or insults. ${ }^{135}$ A victim, however, might have violently attacked the accused in the past. At the time in question, the victim made a non-violent advance. In context, the non-violent act could be a provocation. Despite the open-endedness that "insult" must have, the law does provide some guidance. An insult, we saw, must be "an open and sudden attack or assault without formal preparations; injuriously contemptuous speech or behaviour; scornful utterance or action intended to wound self-respect; an affront; indignity."136 The evidence must support this characterization of the words in question or there is no insult. Specifically (absent honest error by the accused), the evidence must support inferences that the victim had the intention to insult. The judge is entitled to determine whether the evidence supports characterization as an insult. Judges are well able to determine the meaning of words. If there is no evidence that the words spoken had an insulting character or that the words that the accused thought were spoken had this character (to make allowance for an honest error), then no insult occurred. If that was the only alleged provocative act, provocation could not be put to the jury. Thus, a spouse leaving the accused or civil communication by the spouse with the accused cannot, without more, be characterized as an insult.

We do not have a definition of a "wrongful act," although we know that an act that the victim was legally authorized to do cannot be a wrongful act, and we know that wrongful acts are not restricted to illegal acts (although wrongful acts would include illegal acts, such as assaults). The narrow interpretation of "legal act" in s. 232 does not entail that any and all "non-legal acts" (acts legal and illegal, not performed under special authorization) are necessarily provocative. To be a provocation, an act must be “wrongful.” The common law,

"[W]hen a man is taken in adultery ... with another man's wife, if the husband shall stab the adulterer, or knock out his brains, this is bare manslaughter”: Mawgridge, supra note 3 at 1115; Stephen's Digest, supra note 10 at 165; Burbidge's Digest, supra note 12 at 220. The common law approach is consistent with Cory J.'s comment that "[a]ffairs cannot justify murder," since for the common law (and, incidentally for Hunt J.A. in the Tran case), it is not adultery in itself that constitutes provocation, but adultery as witnessed in particular contexts: see Thibert, supra note 51 at para. 22; Tran, supra note 42 at paras. 7-8; infra note 140 and accompanying text. 
on which our Criminal Code is founded, gives a sense of what is intended by "wrongful acts": assault and battery, fighting with deadly weapons or otherwise, unlawful arrest. ${ }^{137}$ These acts involve a physical threat; a threat would be intended by the victim. A manifestly accidental bumping of an accused in a crowded bar would not be provocation. Shoving the accused in the course of a verbal exchange at the bar could be provocation.

Coming upon the act of adultery could cause emotional injury and injury to one's sense of self and understanding of relationships. Mawgridge ${ }^{138}$ does mention property in this context, but the primary motivator of provocation was stated to be jealousy. ${ }^{139}$ Justice Hunt of the Alberta Court of Appeal has recognized that coming upon adultery may (or may not) support a finding of provocation:

\begin{abstract}
At one end of the spectrum, imagine a person returning to the residence where he or she resides with his or her spouse, looking forward to discussing the details of his or her workday with the spouse. He or she finds the spouse engaged in sex with someone else and kills the victim in a rage. Few would dispute that the spouse's behaviour in that context could give at least an air of reality to the existence of an insult, making it necessary to apply the other requirements of section 232(2).

At the other, consider a person who, without permission, enters the home of his former girlfriend with whom he has not had an intimate relationship for several months and whom he knows to be dating another person. Finding her engaged in sex with someone, he kills the lover in a rage. It could not be said there is any air of reality to the suggestion that there is an insult. The former girlfriend and her lover are privately engaging in behaviour that is no one's business but their own, which behaviour the accused has discovered entirely by his own actions. The fact that his discovery may drive him into a homicidal rage will not downgrade his crime. $^{140}$
\end{abstract}

In the case of adultery, no threat would be intended — the intention was to keep the activities secret. Unlike the case of insult, a finding of intentionality (or perceived intentionality) would not be required for all wrongful acts.

One could abstract from the old law that wrongful acts should have to have the tendency to harm some identified "recognizable" interests of the accused and that the harm was either intended or would have been known by the victim to be injurious, if the accused were aware of the acts. ${ }^{141}$ Recognition turns on whether the victim's acts could be understood to injure interests of the accused that are not factually, morally, or legally illegitimate. If acts do not

137 Burbidge’s Digest, supra note 12 at 220.

138 Supra note 3.

139 I note that in the earlier Maddy's Case (1726), 86 E.R. 108 (K.B.), no mention is made of property, only that the sight of his wife and her lover caused the accused exceedingly great provocation.

140 Tran, supra note 42 at paras. 7-8. Nourse has shown that a considerable number of American cases in which provocation was put to the jury did not involve an accused coming upon adultery, but on the spouse's leaving or expressing the desire to leave the accused (resulting in the death of either the spouse or a third party caught up in the departure): Nourse, supra note 125 at 1332, 1334. Nourse's conclusions cannot be directly applied to Canada. A main factor permitting the expansion of provocation to termination of relationship circumstances is the reform of provocation doctrine in American jurisdictions - along Model Penal Code lines - which involves (inter alia), the removal of both the "suddenness" criteria and the ordinary person standard (at 1339); Cynthia Lee, "'Murder and the Reasonable Man' Revisited: A Response to Victoria Nourse” (2005) 3 Ohio State Journal of Criminal Law 301 at 302 [Lee, "Response"].

141 Horder contends that provocations (generally) threaten or challenge the "self-worth" of the accused: Horder, supra note 3 at 142. 
adversely affect any interests that could be recognized by a court, they cannot be wrongful. Provocation extends the benefit of mitigated stigma and punishment to an accused. That benefit — a legal benefit — cannot be based on grounds that contradict the law. A stalker could not claim provocation based on emotional injury relating to his relationship with a star, because there is no relationship. A husband could not claim provocation only on the ground that his interest in controlling or possessing his wife was violated, because there is no such legally recognized interest. In contrast, a husband's emotional attachment to his wife, and a strong emotional response to a betrayal, is not, considered in itself, illegitimate: the emotional response need not have the slightest relationship with any sense of "property" in a spouse, but may arise from expectations relating to the legal covenant of marriage. An adverse emotional reaction to betrayal does not presuppose beliefs that run counter to anyone's Charter rights. That adverse reaction would have to be based on expectations that have a foundation in evidence. It would be wrong to assume, just because of a legal relationship between spouses, that any emotional reactions are necessarily implicated.

My claim is not that the entire chain of conduct — from interpretation of the provocative act to the violence that follows - must be reasonable or rational. The "wrongful act" requirement establishes only a legal restriction on the first stage of the provocation. The provocative act must be one that could be rationally recognized as a provocation, as "wrongful." 142

It has been suggested that s. 232 be amended to provide, for example, that acts or words that undermine the accused's sense of control or possession of another person cannot constitute provocation. ${ }^{143}$ The danger is that drafting will be too broad or too narrow capturing what should be included and what should be excluded is difficult, especially since in interpersonal conflicts multiple strands of injury and reproach may be entwined. The trial judge will be in the best position to sort out whether, in all the circumstances of the case, there is an air of reality to the claim that a wrongful act occurred. If, on the evidence, there is only evidence of a claim of injury based on fiction, or a claim of injury based on an erroneous assessment of legal entitlements (entitlements that could not be law in Canada), then the judge should not put the defence to the jury. The recognition and statutory exclusion problems addressed here have double duty - with respect to the judge's air of reality determination and the jury's application of the ordinary person test. I will address these problems further in connection with the ordinary person test, in Parts III.D.2 and IV.A, below.

My position relating to wrongful acts is similar to the position advanced by Nourse: (1) the law must be consistent - provocation could not be recognized if this would excuse conduct condemned by (at least) other provisions of the law of sentencing; (2) if the victim's conduct were illegal, this would be good evidence showing that the accused responded to a "wrongful act:” Nourse, supra note 125 at 1396, n. 381. My position on these issues differs from Nourse's in two main ways: (1) I do not emphasize the illegality of victims' conduct (indeed, under the jurisprudence, wrongful acts may well be fully legal acts (if not specifically authorized acts). The threshold job of the judge and the jury is to determine whether the accused's appreciation of the act as wrongful falls within the scope of possible (at this point, not reasonable) interpretations by members of the community represented by the judge and the jury members, whether or not the victim's conduct was technically illegal. (2) Nourse seeks to re-invent provocation as, in effect, unauthorized self-help: the accused wrongly stepped in where the state could have stepped in (at 1392-93). I do not seek to explain provocation as even partially a justification (whereas Nourse would see provocation as an excuse in relation to the accused's act, but a justification in relation to the accused's emotion (at 1394)). In my account, the foundation for mitigation of stigma and penalty lies within the accused, not in the victim's conduct. 


\section{In What Lies The EXcuse? The AcCused’s SubJective Response}

Ordinarily, individuals have self-control. For the purposes of criminal law (regardless of what some philosophers might say), we are responsible agents with the power of selfdetermination. ${ }^{144}$ We can choose between different courses of action. If we commit a mens rea or subjective liability offence, we are judged culpable because we chose to do the illegal act when we could have chosen otherwise. ${ }^{145}$ An individual who chooses to kill and does kill is properly labelled and punished as a murderer, assuming no defence, such as self-defence, is available. Prima facie, a provoked accused should be guilty of at least second degree murder (the circumstances of provocation could rebut elevation to first degree murder on the basis of planning and deliberation). The provoked accused wanted to kill, intended to kill, and did kill. Therefore he or she is culpable. To support an excuse, a provoked accused points to an external event, the provocation, which "caused" the mental state in which he or she committed homicide. I will turn now to that mental state and (1) discuss its nature; (2) assess its moral consequences; and (3) respond to some criticisms relating to the law's reliance on that mental state.

\section{The Loss Of THE POWER Of SELF-Control}

The role of the external provocative act makes a claim of provocation resemble a claim of psychological blow non-mental disorder automatism: an external event occurred; the accused's psychological state was adversely affected; the criminal act occurred. The automatism defence (which supports acquittal, or, if based on mental disorder, a verdict of not criminally responsible on account of mental disorder), requires proof that the accused was deprived of free will, choice, or conscious direction of his action. Automatism is "an unconscious, involuntary act, where the mind does not go with what is being done.”146

In contrast, a provoked accused is not an automaton. Provocation induces a passion or emotion (or a set of passions and emotions), usually anger or fear, that is unnaturally strong. Emotion gives the option of reacting violently so much weight that other options are pushed into the background. A provoked accused is very strongly motivated to kill. ${ }^{147}$ One course of conduct is overwhelmingly desirable. The psychological context of the provoked act is therefore very different than the context of a non-provoked act.

The requirement that the accused act "on the sudden," before his passion has a chance to cool, ensures that the excuse applies only to actions committed while the accused is in this extraordinary psychological state. ${ }^{148}$ The provoked accused reacts before he has an opportunity to collect himself and decide whether or not to attack the victim.

Richard Holton \& Stephen Shute, "Self-Control in the Modern Provocation Defence” (2007) 27 Oxford J. Legal Stud. 49.

Ruzic, supra note 117 at paras. 34, 45.

Stone, supra note 35 at para. 155, citing R. v. K. (1970), 3 C.C.C. (2d) 84 at 84 (Ont. H.C.).

"Provocation may, of course, inspire the intent required to constitute murder": Campbell, supra note 30 at 683 .

By way of analogy, spontaneous declarations are an exception to the hearsay rule because (in part) the declarations were made under the influence of a startling event before the declarant had the opportunity to collect himself and concoct a statement (or at least taint the statement through reflection and imagination). 
Victoria Nourse has argued that we should not accept the view that passion and reason are separate and incompatible. ${ }^{149}$ She rightly points out that emotional responses have cognitive aspects. It makes sense to ask, "why do you feel that way?"; and it makes sense to reply "I am angry because...." The fact that an accused is overtaken by passion does not mean that the accused begins to lash out randomly at anyone or anything. Even when under the influence of strong passion, the accused targets his violence at the source of the provocation, as a response to that provocation. The provoked accused may not have good reasons for his or her behaviour, but the accused still has reasons.

Nourse's views are useful when considering ordinary emotions, even strong emotions. Talk of reasonableness of emotion can be misleading when dealing with provocation, though, since it can underplay the qualitative emotional shift that captures the provoked accused. The common law and statute use the old term "passion" to describe the emotion that dominates the accused. The term is now generally used as a synonym for emotion or for a strongly preferred interest ("he pursued his passion”). The term originated from Latin, derived from the verb "to suffer." 150 Its main original use was in Christian theology, concerning, for example, the Passion of Jesus or the passions of saints and martyrs. ${ }^{151}$ It came to be used to describe suffering and affliction before being used to describe strong or intense emotions. The old sense of passion seems to capture the experience of provocation: the passion is an external force that deprives an accused of his ordinary power of choice. The accused is acted upon by a force that is in him but not of him. According to J. Glenn Gray, “[p]assion ... is an undergoing, a being acted upon from without in contrast to an action which is initiated within. As such it is the clearest contradiction of freedom." ${ }^{152}$ This distinction between anger and rage is critical. The law is not concerned with rational anger; it is concerned with loss of self-control. It is concerned with unreason breaking through and into human acts. Gray would distinguish the passion that grips the accused in provocation from the emotion of everyday life. The passion that would take most accuseds is not properly anger, but rage: "Rage is in every respect a passion, not an emotion. It has little in common with anger, which frequently is a necessary and desirable emotion leading to action. Rage grips us from without, takes us out of ourselves. It is ekstasis in the bad, even evil, sense of the word."153

Although the influence of emotion is very strong, it cannot have made choice impossible. That would take the events out of the realm of provocation and into the doctrine of automatism - if choice were impossible, the mind would observe what is being done but could do nothing to stop it. In circumstances of provocation, choice is not impossible but practically very difficult. ${ }^{154}$

J. Glenn Gray, “Understanding Violence Philosophically” in J. Glenn Gray, ed., On Understanding Violence Philosophically and Other Essays (New York: Harper \& Row, 1970) 1 at 11. 


\section{MORAL IMPLiCATIONS OF THE LOSS OF THE POWER OF SELF-CONTROL}

The passion induced by provocation entails that provoked accused are not on the same moral footing as non-provoked accused. Provoked accused are, practically, constrained in their choices. Their condition is akin to the "moral involuntariness" that underlies full excuses, such as necessity and duress. The similarity lies in the provoked accused's practical inability to choose to act other than in retaliation for the provocation. But why, one might ask, should this peculiar mental state receive special treatment by the law? Love or compassion could motivate a killing, as in euthanasia or "mercy killing." Desperation or fear of later conduct could motivate the killing of a batterer or individual who poses a serious (but not imminent) danger to others. A purpose of provocation is to permit recognition that blameworthiness for homicide is not uniform - yet the defence excludes multiple circumstances in which blameworthiness might be mitigated.

The basis for the law's recognition of provocation is twofold. First, as an excuse and only an excuse, it makes no claim that the accused's conduct was right. Provocation involves no appeal to any standard of right above the law. ${ }^{155}$ The provoked killer professes no superior moral judgment — his or her judgment was impaired by emotion. The defence, as has been contended, is a concession to human weakness, not an acceptance that the accused can rightly judge who should live and who should die. Second, provocation relies on an extension of the "realism" or what might be called the "correspondence theory" implicit in the criminal law. Stigma and punishment cannot be simply attributed to conduct: stigma and punishment should correspond to the level of blameworthiness of the conduct. There should be a relationship of proportionality between stigma and punishment and the accused's culpable mental state. ${ }^{156}$ The emotional constraints bearing on the provoked accused arguably differentiate the accused from an unprovoked killer. While the provoked killer did intend to kill, the provoked accused did not have the same degree of freedom of choice as the unprovoked killer. Hence, that diminished blameworthiness should be reflected in diminished stigma and potential punishment.

Provocation goes no farther than to support diminished stigma and potential lowered punishment - it does not absolve of liability. While the provoked killer did not (ex hypothesi) have the same freedom of choice as an unprovoked killer, the state of provocation does not match the moral involuntariness that fully excuses the accused through defences like necessity or duress. The relationship between provocation and moral involuntariness defences should not be overstated. There are differences. The other excuses involve constraints on choice respecting action to be taken to avert a threat - the action is pre-

See Perka, supra note 127 at 248.

See R. v. Martineau, [1990] 2 S.C.R. 633 at 645:

A conviction for murder carries with it the most severe stigma and punishment of any crime in our society. The principles of fundamental justice require, because of the special nature of the stigma attached to a conviction for murder, and the available penalties, a mens rea reflecting the particular nature of that crime. The effect of s. 213 is to violate the principle that punishment must be proportionate to the moral blameworthiness of the offender, or as Professor Hart puts it in Punishment and Responsibility (1968), at p. 162, the fundamental principle of a morally based system of law that those causing harm intentionally be punished more severely than those causing harm unintentionally. The rationale underlying the principle that subjective foresight of death is required before a person is labelled and punished as a murderer is linked to the more general principle that criminal liability for a particular result is not justified except where the actor possesses a culpable mental state in respect of that result. 
emptive or prospective, undertaken to avoid harm. ${ }^{157}$ The response of a provoked accused is retrospective, in that he or she is responding to a provocation that has already occurred. The accused acts not to avoid harm but because he or she was harmed. ${ }^{158}$ The other excuses judge the proportionality of what was actually done. Provocation looks only to the reasons for the loss of self-control. The other excuses assess whether legal alternatives to law-breaking were available. ${ }^{159}$ In provocation cases, legal alternatives are always available - the accused could have walked away. Other options for dealing with the victim were not closed because of threats of serious injury to the accused or third parties. The other excuses support a full acquittal. Provocation does not. Because the provoked accused does act voluntarily and could, in theory, act otherwise, he is responsible. Because of the difficulty of choosing otherwise, he is not as culpable as an accused who was not provoked (or otherwise not justified in killing). Because the provoked accused did kill and his acts could not be proportional to the provocation, he remains liable for manslaughter. ${ }^{160}$

One might wonder whether provocation is constitutionally protected. If provocation does pick out a particular state of mind that is less blameworthy than the mens rea for murder unaffected by a loss of the power of self-control, then if the provocation provisions were repealed, would the conviction of a (formerly) provoked accused for murder violate the principles of fundamental justice? A provoked killer did intend to kill, and so could be judged to have a sufficiently blameworthy mens rea to be classified as a murderer. ${ }^{161}$ Furthermore, since provocation does not involve moral involuntariness of the sort recognized for other excuses, the argument could not be made that the absence of the defence would wrongly permit conviction of the morally involuntary. While it might be desirable that all circumstances that tend to show diminished blameworthiness should be available to reduce murder to manslaughter, desirability is not the same as constitutional necessity. Provocation - unlike some other circumstances that diminish blameworthiness - happens to have received centuries of formal legal recognition. This is a fact of some significance, since its long use tends to show both its utility and its interconnection with our legal conceptualizations of homicide offences. ${ }^{162}$ Michael Plaxton, though, considers this linkage to be merely a historical accident that does not reflect any intrinsic moral superiority of the defence. ${ }^{163}$ Critics of the defence would argue that it is less morally defensible as a means to reduce stigma and punishment than other sorts of excusing circumstances not currently recognized by the Criminal Code or common law.

I will not attempt to provide a final answer here to the question of the constitutional status of provocation. My suspicion is that, given that (i) provoked actions are both voluntary in fact and morally voluntary; (ii) provoked accuseds intended to kill and did kill; and (iii) provocation analysis does not contain the restrictions and controls of the other excuses, convicting a provoked accused of murder would not violate fundamental justice. Provocation doctrine does assist in classifying blameworthiness, and it is desirable to have a doctrine that

Colvin \& Anand, supra note 42 at 374.

Ibid.

Ibid. at 375; Roach, supra note 44 at 372.

Coughlan, supra note 118 at 182-84.

Cameron, supra note 42.

R. v. Creighton, [1993] 3 S.C.R. 3 at 16-17; Ruzic, supra note 117 at para. 28.

Michael C. Plaxton, “On Not Taking Provocation Too Seriously: A Partial Reply to Stephen Coughlan” (2004) 8 Can. Crim. L. Rev. 377; Roach, supra note 44 at 372-73. 
can do this job. However, not everything that is desirable is constitutional, and not everything that is constitutional is desirable.

\section{CRITICISMS}

a. Myth

A response to the account of the mental state of the provoked accused is that it is fiction. The state of being deprived of the power of self-control was invented by judges and simply repeated in statute. The mental state is not validated by psychology. ${ }^{164}$

In answer, we do have 400 years of confirming data in the form of testimony and other evidence relating to provocation. Granted, the data is self-reported, but this is no different in form than responses to questionnaires, surveys, or interviews, save that the evidence has been given under oath. Granted, the self-reporting of provocation has served strong selfinterest — for some centuries it could literally make a difference between life and death, and it can still make a substantial difference to time served in prison. Dire prospects could motivate the accused to skew accounts of what happened - but this is true for all kinds of testimony by the accused, regardless of the defence advanced. Even if the accused tell the truth (apart from only raising a reasonable doubt) in a small percentage of cases, over 400 years we would have a significant number of confirming accounts. The lack of confirmation by psychologists is not proof that the state does not exist. Experimental replication of rage states would doubtless be impossible as a matter of research ethics. Psychologists would not be present when alleged instances of provocation occurred in the field. Psychologists could interview those who claim to have been provoked, but then we would return to the selfreporting issue.

We do have 400 years of judicial recognition of the defence. Provocation also has a home in ordinary language and ordinary moral assessment. General acceptance, of course, is not proof of accuracy. We have believed in falsehoods for longer periods. Yet, general acceptance is a factor to be taken into account when assessing the merit of a theory.

What might urge a denial of the existence of provocation is the narrow and paradoxical nature of the relevant state of mind. The accused acts voluntarily, but under very strong psychological compulsion. The accused chooses to kill, but his or her power of choice is severely degraded. The accused is self-determined, but without self-control. We must resist the impulse to view our intentional and moral lives too simplistically. Finely parsed mental states do exist, which ordinary language attempts to capture. ${ }^{165}$ Austin reminds us, for example, that "we can act at once on impulse and intentionally, or ... we can do an action intentionally yet for all that not deliberately, still less on purpose.”" ${ }^{\text {„166 }}$ Moreover, the law has made it its business to finely parse subjective states to assign degrees of blameworthiness. For example, the law distinguishes between the outright intention to produce a consequence, recklessness involving subjective advertence to consequences or the foresight of probable

LC, Partial Defences, supra note 69 at para. 3.30; NAWL, Provocation, supra note 40 at para. 2.2. A main burden of "A Plea for Excuses" is to demonstrate the moral nuance that can be made visible through studying our language of excuse: see Austin, supra note 112 at 182. Ibid. at 195. 
— or even highly probable — consequences, ${ }^{167}$ and foresight that a consequence is certain or substantially certain. ${ }^{168}$ Provocation might seem too unlikely to exist, but only if human moral life is assumed to be less complicated than it actually is.

\section{b. $\quad$ Mere Assertion}

One might concede that the state of mind relied on by the provocation doctrine could exist, but argue that, in many cases, accuseds' claims to be provoked are lies. This is a particular concern in domestic homicide cases. The defence, it could be contended, is based on the mere assertions of the accused. Critics point out that provocation must be founded on a deprivation of self-control, but those claiming provocation often lose control in only selected situations. Far from having lost control, the accused choose their time and their victims. Victims tend not to pose physical threats to the accused. Offence is taken when the risk ofeffective retaliation is small. ${ }^{169}$ Those claiming provocation have tended not to respond with violence outside of (in particular) domestic settings - they have not, for example, attacked their employers or workplace supervisors. ${ }^{170}$ Some abusive men have confirmed that when attacking their spouses, they felt not lack of control, but that they precisely had control. ${ }^{171}$

In particular cases, the critics are doubtless right. This realization, though, does not take us anywhere except back to where we are. The possibility of concocted testimony concerns the whole of litigation, especially proof of mens rea. Mere assertion of a defence (if such bare testimony were ever provided) could not support a finding of deprivation of self-control. So long as the accused provides an account with some detail and particularity, the judge who cannot decide credibility and weight - must leave the defence to the jury: ${ }^{172}$

At times, as in the case at bar, proof of the defence may rest on little more than the accused's own evidence.

Verification of a spurious claim of duress may prove difficult. Hence, courts should be alive to the need to apply reasonable, but strict standards for the application of the defence. In the end, much will depend on the evaluation of the evidence and on the soundness of the instructions given to jurors during a jury trial. ${ }^{173}$

If accuseds testify, they may be cross-examined and weaknesses in their stories may be explored. Similar fact evidence should be admissible on the issue of whether the violence at issue was one more example in a series of controlled attacks. The critics' concerns - and they are legitimate — should sharpen prosecutors' challenges of accuseds' evidence, but the concerns do not justify any special restrictions on evidence of provocation.

R. v. Buzzanga (1979), 49 C.C.C. (2d) 369 at 379, 384 (Ont. C.A.).

Ibid. at 383-85.

LC, Partial Defences, supra note 69 at para 3.28 .

Lee, supra note 9 at 28.

Ibid. at 28-29.

R. v. Fontaine, 2004 SCC 27, [2004] 1 S.C.R. 702 at para. 93; R. v. Esau, [1997] 2 S.C.R. 777 at paras. 14-15; R. v. Cinous, 2002 SCC 29, [2002] 2 S.C.R. 3 at paras. 88, 108.

Ruzic, supra note 117 at para. 59. 
c. Privileging Anger

Critics have contended that the provocation rules, as currently drafted, privilege fear and anger. ${ }^{174} \mathrm{~A}$ purpose of provocation is to permit recognition that blameworthiness for homicide is not uniform - yet the defence excludes multiple circumstances in which blameworthiness might be mitigated. These observations are in aid of a call for an expansion of the provocation rules.

The argument that provocation is not a broad enough defence is not new. Stephen was aware of the limits of the doctrine. He provided a list of circumstances that diminish culpability for murder:

4. Cases in which the deceased person consented to his own death; as, for instance, A. and B. agree to poison themselves together. A. provides poison, of which both drink ; B. dies, and A. recovers.

5. Cases in which the motives of the offender are compassion, despair, or the like. A mother, deserted by her husband and unable to provide for her child, drowns it. A physician administers deadly poison to a person dying of hydrophobia, in order to shorten his agonies.

6. Cases in which a woman kills her new-born child under the distress of mind and fear of shame caused by child-birth. I believe that no one has been executed for such an offence for about forty years. ${ }^{175}$

A variety of circumstances mitigating murder were therefore expressly in the mind of one of the drafters of the Draft Code, on which our Criminal Code was founded. Some of these circumstances have received statutory recognition — item 6 was captured in the infanticide provisions of the Criminal Code ${ }^{176}$ some have not. The problem, if any, is not with the provocation excuse, but with the failure of Parliament to assign Criminal Code provisions to the non-provocation circumstances.

Provocation, like necessity, duress, and self-defence, has a particular structure that permits it to function as an excuse. It works because (in part) the accused acted on the sudden, while in a state of radically diminished self-control, which arose because of a sudden provocation. The excuse could not be changed to accommodate other types of circumstances without ceasing to be the excuse of provocation. This is not to say that arguments cannot be made to support other types of excuses. ${ }^{177}$ But if an excuse does not involve sudden action, loss of self-control, or a sudden provocation, whatever the proper description for the excuse may be and whatever the basis for recognizing the excuse may be, it will not be an excuse of provocation. The moral basis for recognizing a defence for euthanasia is simply not the same as that for recognizing an excuse for provocation.

LC, Partial Defences, supra note 69 at para. 3.36; Justice Canada, Provocation, supra note 3 at 9; NAWL, Provocation, supra note 40 at para. 2.3; LRCC, Homicide, supra note 25 at 69.

Stephen, History, supra note 6 at 86.

Criminal Code, supra note 27, s. 233.

"Some people suggest that if the defence of provocation remains for murder, a new, parallel defence of provocation should be added to reflect compassion for the situations women are in. The new defence could reduce a murder charge to manslaughter when the murder was provoked by prolonged and severe domestic abuse or oppression. The defence could recognize the slow-building effect of such abuse": Justice Canada, Reforming the General Part, supra note 37 at 22; LC, Murder, supra note 39 at para. 5.24 . 


\section{d. Privileging Male Responses}

A related criticism is that the tendency to react to wrongful acts or insults with sudden homicidal violence is a male tendency, not a female tendency. ${ }^{178}$ Women, it is contended, would tend not to react with violence on the sudden, but only following extended prejudicial interactions (long-term abuse is the paradigm); their response could be motivated by fear or anger, but it is born from desperation. ${ }^{179}$ The provocation defence, then, does not provide equal protection to women, since it does not extend an excuse to women in the sorts of circumstances in which they are likely to kill.

The transformation urged for provocation is not like the transformation successfully imposed on the defence of duress in Ruzic. ${ }^{180}$ Section 17 of the Criminal Code imposed strict conditions of immediacy and presence on the availability of duress - that is, circumstances in which an accused is compelled to act because of the threats of immediate bodily harm by a third party to the accused or another person. ${ }^{181}$ Individuals could find themselves under duress (under compulsion by threats), but because the person making the threats was not present (for example, he was at the accused's home, holding the accused's children hostage) and because the threat of harm was not immediate, the accused could not rely on manifest compulsion, the very species of excuse that the section is designed to recognize. The "immediacy" and "presence" conditions were found to violate fundamental justice and were read out of s. $17 .^{182}$ In contrast, the emotion and gender-based challenges do not point to circumstances that we would naturally call "provocation" - sudden responses based on sudden incidents that deprive accused of the power of self-control. Individuals who are asserted to merit a defence under the emotion or gender-based challenges do not have that defence denied because of a technical defect in the drafting of the provocation provisions; they are not provoked.

Again, the problem is not with provocation itself, but with the absence of another sort of defence. This defence would not have provocation's suddenness requirements and need not require that the accused be reduced to a state in which the accused is deprived of self-control. Rather than having provocation as its model, a better defence might be a refinement of the defence of self-defence. ${ }^{183}$ One practical drawback with expanding the provocation defence would be that more men in more circumstances would have access to it. ${ }^{184}$

Finally, the claim that men tend to behave in one way and women in another should be approached with some caution. Essentialism, even in the service of progressive causes, should be avoided. Not all men behave the same way, and not all women behave the same

Justice Canada, Reforming the General Part, ibid. See LC, Murder, ibid. at para. 5.18:

In addition, the requirement of a loss of self-control has been widely criticised as privileging men's typical reactions to provocation over women's typical reactions. Women's reactions to provocation are less likely to involve a "loss of self-control", as such, and more likely to be comprised of a combination of anger, fear, frustration and a sense of desperation. This can make it difficult or impossible for women to satisfy the loss of self-control requirement, even where they otherwise deserve at least a partial defence.

LC, Murder, ibid.

Ruzic, supra note 117.

Criminal Code, supra note 27, s. 17.

Ruzic, supra note 117 at para. 55.

NAWL, Provocation, supra note 40 at para. 1.6.4.

Justice Canada, Provocation, supra note 3 at 15. 
way. In particular, the conduct of some women may exactly fit the provocation defence, and they would and should, therefore, have the benefit of its excuse. Alternatively, one could accept that men do kill more often than women, that they do respond to provocation differently, and that the provocation excuse is male-oriented. ${ }^{185}$ Of course, men commit nearly all crimes more often than women, there are far more men in prison than women, and while men kill more women than women kill men, men kill more men than women. ${ }^{186}$ If it is true that the provocation defence, as currently drafted, does capture a legitimate excuse, then those who meet its conditions should have the excuse available, even if most of those who rely on the defence are men. The fact that they are men does not make them more culpable. To eliminate the defence would be unfair to those who would satisfy its conditions - male and female. If there are circumstances that reduce culpability for murder that are not in the Criminal Code, the solution is to draft new appropriate provisions to add to the number of excuses, not subtract from it.

If the provocation excuse does pick out an appropriate subjective state of an accused (without barring the possibility of other sorts of excuses turning on other subjective states), the account of the provocation excuse is partly done, but only partly done. The provocation excuse is not made out just because of the accused's subjective state, just because the accused lost self-control. A loss of self-control could be pitied. It could be itself blameworthy - the accused should not have lost his self-control. The provocation excuse requires satisfaction of an objective criterion. The loss of self-control was not merely the expression of the accused's personal frailty. The accused exhibited a frailty that "we" all share. I now turn to an examination of this objective criterion for the provocation excuse.

\section{In WHAT LIES THE EXCUSE? THE OBJECTIVE ELEMENT}

The Criminal Code provides that the wrongful act or insult that elicits the accused's loss of self-control must be "of such a nature as to be sufficient to deprive an ordinary person of the power of self-control." 187 The jury must decide "whether a particular wrongful act or insult amounted to provocation." 188 An objective test supplementing a subjective test is a feature common to necessity, duress, and self-defence. The objective test ensures that a minimum standard of conduct is embodied in the defence. The accused cannot be acquitted just because he or she thought it was the right thing to do in the circumstances, or, as in the case of provocation, just because he or she lost self-control.

As indicated above, the ordinary person test has two elements - cognitive and volitional. With respect to the cognitive element, the jury should receive all evidence relevant to understanding the accused's perspective on the alleged wrongful act or insult: "an insulting remark or gesture has to be placed in context before the extent of its provocativeness can be realistically assessed." ${ }^{189}$ The question of whether the ordinary person would have reacted in the same manner as the accused cannot be answered unless the jury knows what

Joshua Dressler, “When ‘Heterosexual’ Men Kill ‘Homosexual’ Men: Reflections on Provocation Law, Sexual Advances, and the ‘Reasonable Man’ Standard” (1995) 85 J. Crim. L. \& Criminology 726 at 735, 756.

Ibid. at 735-36.

Criminal Code, supra note 27, s. 232(2).

Ibid., s. 232(3)(a).

Hill, supra note 4 at para. 69. 
provocation the accused actually confronted. With respect to the volitional element, individual characteristics that would make the accused less able to resist his emotions or more inclined to follow them should not be taken into account, although the ordinary person is to be conceived as being of the same age and sex as the accused. The volitional element remains objective.

The objective component of the provocation excuse is the subject of numerous challenges, including whether the test could ever properly excuse homicide; whether the test must collapse into subjectivity because of the need to introduce individualizing factors; and whether the law or the application of the law promotes interests inimical to the individual right to equal protection under the law.

\section{ORDINARY PERSONS Do NOT KILL}

The first challenge is frequently heard: ordinary people do not fly into homicidal rages. The accused must appeal to what "we" would do in like circumstances. But the "we" that is our community in twenty-first century Canada does not include individuals who, without any other justification or excusing circumstance, hear an insult, lose self-control, and kill. Hence, the provocation defence should excuse no one. ${ }^{190}$ It could and should be eliminated.

The claim made in the challenge is right. The ordinary person does not kill. It is not reasonable for one person to kill another simply because of a wrongful act or insult. What the challenge misses is that provocation does not require that the ordinary person kills; instead, it speaks to the circumstances in which the ordinary person ceases to be the ordinary person and kills. ${ }^{191}$ Killing is not defended as reasonable. Killing is not defended as rational. The challenge presupposes a sort of Cartesian monism, as if we were, in essence, unified rational egos. The provocation defence presupposes a more complex notion of what it means to be human.

We might think of the ordinary person (or the reasonable person) as our good self. It is aware of all relevant facts. It makes all appropriate inquiries. It conducts itself according to socially beneficial standards. It doesn't fail to do what it should do. Sometimes we embody this ordinary person. Sometimes we do not. Behind the provocation doctrine is the realization that rationality expresses only part of human experience. We are not single rational egos. Our selves are more a collection of desires and intentions, emotions and instincts. Our rational self may usually be the chair of this assembly, but it is liable to be usurped.

Provocation speaks to circumstances in which typical rational control fails. It speaks to the moment when reason is dethroned and unreason governs. The potentiality for unreason is part of the silent backdrop of jury determination of provocation. The jury is to expressly apply the ordinary person test. What the jury brings to this determination is not only the application of that test, but its knowledge of the limits of the ordinary person, its knowledge person would have reacted by killing NOC, but rather whether the ordinary person, confronted with the same wrongful act or insult in the same circumstances, would have lost the power of self control": Canadian Judicial Council, supra note 59 at para. 3. 
of when — despite all commitments to rational goals and values — the ordinary person is displaced. There is no jury instruction and no jurisprudence addressing this other part of the jury's collective experience. But this is where the self goes, when abandoned to provocation.

Obviously, people are provoked and do kill. We can claim that we would not do the same, and we would probably be right. Yet, our control does not prove enough. If it were true that "we" do not fly into rages, and provoked violence is inconceivable for us, then those individuals who do engage in provoked violence would, in some way, for some reason, not be like us; they would belong to a different group. We would be presupposing some sort of qualitative difference between us, the law-abiding, and the other - the murderous criminal. This sort of thinking would — at least — run afoul of the commitment to equality that underlies other challenges to the provocation excuse. I suspect that progressive critics of provocation would not want to venture far down this particular road.

The reality is that individuals will, in (what should be) extreme circumstances, respond to provocations with homicidal violence. For centuries, the courts have consistently recognized the potential for violence in our hearts and have explained the provocation excuse as a concession to our human frailty — not just the frailty of the accused, but our frailty. ${ }^{192}$ The potentiality for homicidal violence is part of our human condition, at least for those in the Western tradition. We can see in our foundational literature, which reflects the archetypes of our collective unconscious or our Western way of being, ${ }^{193}$ our deep linkages to violence. We get barely four chapters into Genesis before Cain slays Abel. ${ }^{194}$ There follow throughout the Tanak, or Old Testament, ${ }^{195}$ multiple accounts of violent acts. Homer is replete with violence, as are the Greek and Norse myths. ${ }^{196}$ Like it or not, we have a history of violence.

One might suggest, in light of these observations, that provocation does not so much have a moral foundation but an existential foundation.

Many may live their lives untouched by actual violence. Through our imagination, though, we should be able to project beyond who we are and what we have done to what we could do - not as reasonable persons, but as unreasonable persons. If we cannot project beyond ourselves to what we share with others, then no ordinary person or reasonable person test is possible. No jury and no judge would have a warrant to speak for others. ${ }^{197}$

Hill, supra note 4 at para. 14; Thibert, supra note 51 at paras. 4, 22; D.L., supra note 64 at para. 20; Campbell, supra note 30 at 682.

193 See Carl G. Jung, "The Concept of the Collective Unconscious” in Joseph Campbell, ed., The Portable Jung, trans. by R.F.C. Hull (New York: Penguin Books, 1976) 59.

194 Herbert G. May \& Bruce M. Metzger, eds., The New Oxford Annotated Bible with Apocrypha (New York: Oxford University Press, 1977), Genesis 4.8.

195 Norman K. Gottwald, The Hebrew Bible: A Socio-Literary Introduction (Philadelphia: Fortress Press, 1985) at 6, n. 1.

196 See Thomas Bulfinch, Bulfinch's Mythology: The Age of Fable (New York: Meridian, 1995).

197 Elsewhere, I have described our ability to speak for others as a matter of our constitutional faith: Wayne Renke, "Invoking Independence: Judicial Independence as a No-Cut Wage Guarantee" Points of View, No. 5 (Edmonton: Centre for Constitutional Studies, 1994) at 3-5, online: Centre for Constitutional Studies <http://www.law.ualberta.ca/centres/ccs/uploads/PointsofViewNo5.pdf > . 


\section{APPROPRIATE JURY CONSIDERATIONS}

Denying the irrational is a mistake. It is equally a mistake to deny the rational. The ordinary person does not take offence too quickly. The ordinary person is not bound to take offence at every slight that every accused might rely on. The ordinary person must decide the nature of the alleged provocations. The ordinary person ordinarily has the fortitude to resist the irrational and not attack.

The jury should receive evidence sufficient to permit it to understand the situation that the accused confronted. The jury, though, is not bound to recognize provocation where the accused found it. The evidence relating to the accused and the background experience the jury members bring to their job require supplementation. The jury should be given sufficient information to understand the standards governing the ordinary person. As a first consideration, the ordinary person should not act inconsistently with the law. Provocation mitigates stigma and punishment. It should not be permitted to do so by relying on evidence and inferences that have been expressly specified as aggravating factors in sentencing. The Criminal Code states the following respecting aggravating factors in sentencing:

(i) evidence that the offence was motivated by bias, prejudice or hate based on race, national or ethnic origin, language, colour, religion, sex, age, mental or physical disability, sexual orientation, or any other similar factor,

(ii) evidence that the offender, in committing the offence, abused the offender's spouse or common-law partner,

(iii) evidence that the offender, in committing the offence, abused a position of trust or authority in relation to the victim,

shall be deemed to be aggravating circumstances. ${ }^{198}$

To the extent that the accused's provocation claim relied on any of these aggravating factors, provocation cannot be recognized.

More generally, the ordinary person must be understood to abide by basic Canadian values:

In this case, however, the appellant's religious and cultural beliefs are not the target of the alleged insult. Rather, the appellant's religious and cultural beliefs are said to render the words spoken by Aysar highly insulting. The difficult problem, as I see it, is that the alleged beliefs which give the insult added gravity are premised on the notion that women are inferior to men and that violence against women is in some circumstances accepted, if not encouraged. These beliefs are antithetical to fundamental Canadian values, including gender equality. It is arguable that as a matter of criminal law policy, the “ordinary person” cannot be fixed with beliefs that are irreconcilable with fundamental Canadian values. Criminal law may simply not 
accept that a belief system which is contrary to those fundamental values should somehow provide the basis for a partial defence to murder. ${ }^{199}$

The ordinary person should not be imagined to be evil or ignorant. Our fundamental values are expressed in our law, and the ordinary person would both know this and respect that law. ${ }^{200}$ The ordinary person, as an ordinary Canadian, would be defined, at least in part, by an acceptance of our fundamental values. ${ }^{201}$ Furthermore, the ordinary person test is a legal rule. It should be interpreted consistently with our fundamental values. In Stone, Bastarache J. wrote as follows:

It is incumbent on the judiciary to bring the law into harmony with prevailing social values.... This Court's jurisprudence also indicates that the law must evolve to reflect changing social values regarding the status between men and women.

In Weatherall v. Canada (Attorney General) ... this Court recognized the "historical trend of violence perpetrated by men against women”. More specifically, in Lavallee ... the growing social awareness of the problem of domestic violence was recognized by this Court. In my opinion, these cases indicate that prevailing social values mandate that the moral responsibility of offenders be assessed in the context of equality between men and women in general, and spouses in particular. Clearly, spousal killings involve the breach of a socially recognized and valued trust and must be recognized as a serious aggravating factor under s. $718.2(a)(\mathrm{ii}) .^{202}$

Humaid, supra note 52 at 480 ; see also Tran, supra note 42 at para. 63:

More broadly, the respondent's submission would eliminate any significance of the maturity of Canadian social norms regarding the only two acceptable responses to adultery: forgiveness and family rehabilitation, or civilized termination of the marriage. There is no justification for rolling social standards back to the era of coverture. Indeed, Parliament and the Legislature, decades ago, eliminated adultery from relevance on the subject of division of matrimonial property or other collateral relief associated with divorce. It no longer causes the adulterer to completely forfeit the regard of society. Adultery is not outlawry. No support exists for clawing back legal opprobrium for adultery by the declaratory effect of adding it to the legal definition of provocation. At the very least, no explosion of intentional killing should be excusable by the mere fact of discovering 'adultery' done by a person who has elected to live separate and apart from her spouse. The 'ordinary person' should not be fixed with beliefs that are irreconcilable with fundamental Canadian values.

NAWL, Provocation, supra note 40 at para. 2.4; Lee, supra note 9 at 243; R. v. S. (R.D.), [1997] 3

S.C.R. 484 at para. 46 :

The reasonable person .... is an informed and right-minded member of the community, a community which, in Canada, supports the fundamental principles entrenched in the Constitution by the Canadian Charter of Rights and Freedoms. Those fundamental principles include the principles of equality set out in s. 15 of the Charter and endorsed in nation-wide quasiconstitutional provincial and federal human rights legislation.

Consider former Prime Minister Tony Blair's comments on the meaning of being British in Tony Blair,

"The Duty to Integrate: Shared British Values" ("Our Nation's Future” Lecture, delivered at Downing

Street, London, 8 December 2006), online: Number10 <http://www.number10.gov.uk/ Page10563>: So it is not that we need to dispense with multicultural Britain. On the contrary we should continue celebrating it. But we need - in the face of the challenge to our values - to re-assert also the duty to integrate, to stress what we hold in common and to say: these are the shared boundaries within which we all are obliged to live, precisely in order to preserve our right to our own different faiths, races and creeds.... So: how do we do this? ... Partly the answer lies in precisely defining our common values and making it clear that we expect all our citizens to conform to them. Obedience to the rule of law, to democratic decision-making about who governs us, to freedom from violence and discrimination are not optional for British citizens. They are what being British is about. Being British carries rights. It also carries duties. And those duties take clear precedence over any cultural or religious practice. 
An accused's understanding of an alleged provocation may be conditioned by express, implicit, or inferred beliefs, judgments, or attitudes that are antithetical to fundamental Canadian values. If, on the evidence, the alleged provocation could only be the product of such beliefs, judgments, or attitudes, the defence should be rejected.

If the jury accepts that a wrongful act or insult could be found on the evidence, the jury must determine whether the ordinary person could have resisted the provocation. Provocation should be recognized only at that point where the ordinary person's control has been taken to its limit, and that limit has been passed. What is critical, then, is to ensure that the measure of the ordinary person's control — the volitional element of the ordinary person test — not be reduced or undermined. Save for taking into account the age and sex of the accused, this test should not be contextualized. It is not the accused's self-control but the self-control that the jury understands that is to be applied. In particular, "the hypothetical reasonable person should not be imbued with cultural traits that may lessen standards of self-restraint."203

Would this suggested information for the jury go too far? Coughlan comments that "one would expect that a list of reasons that are somehow legitimate justifications for flying into a homicidal rage but are also consistent with fundamental Canadian values would have to be a diminishingly small one." ${ }^{204}$ I have two responses: first, provocation should be a rarely successful defence. It should be available only in extreme circumstances, when accused are brought to their true limits. Second, it is true that homicidal rage is consistent with virtually no fundamental Canadian values. My point, however, is that provocation does not lie in those values, but outside those values. The ordinary person can be provoked, even though the ordinary person accepts those fundamental values.

The standards that the jury should be attentive to in applying the ordinary person test are standards that the trial judge should consider in deciding whether a defence of provocation has an air of reality. The jury decides whether the defence should be recognized (at least, whether there is doubt). The judge decides whether the defence could be recognized. That determination requires a finding that the bases for the provocation would permit recognition by the jury. If a provocation claim relies only on grounds that would not permit the claim to be recognized by the jury, the judge should not give over the defence to the jury for its consideration.

\section{CAN JURIES BE TRUSTED?}

A critic might respond that this - that all of this - is nothing but words. Specifically, in its concrete application, the law of provocation has been a tool used to reinforce the conception of women as men's property ${ }^{205}$ and to "[legitimate] murderous 'loss of self control' as a response to a woman's attempts to assert her autonomy."206 The defence benefits men, because "more men than women kill their partners." 207 The ordinary person test is no

203 Paciocco, supra note 100 at 41.

204 Steve Coughlan, Case Comment on R. v. Humaid, (2006) 37 C.R. (6th) 347 at 351; see Colvin \& Anand, supra note 42 at 385.

NAWL, Provocation, supra note 40 at para. 1.2.

Ibid.

Lee, supra note 9 at 26. 
shield for women, because the test "has historically been interpreted from a male perspective and ... the gender-neutral language in fact masks a gender-based standard.”208

These claims are claims about the facts. The data must be approached cautiously. We should not make the mistake of substituting judicial reasons for jury decisions. Judges, it appears, are not reluctant to put the defence to juries - after all, the question of whether provocation is made out is expressly for the jury, and the judge does play only a threshold role. Juries, though, "are not particularly prone to accepting such defences,"209 at least if the accused is male. ${ }^{210}$ If provocation is successfully used to reduce murder to manslaughter, the accused often receives a significant sentence. A 2003 federal Department of Justice working group report reviewed 49 cases dealing with sentencing for manslaughter in cases involving intimate relationships since 1991:

[T]here is a significant difference between the range of sentences for male and female offenders, which reflects the different contexts in which male and female offenders in this sample killed their partners. Sentences for male offenders ranged from 46 months to life, while sentences for female offenders ranged from suspended sentences with probation to five years.

Most of the male offenders (21 of 30 cases) received sentences in the 6 - 12 year range. Of the remainder, four were sentenced to less than 6 years, and five to more than 12 years.

Justice Canada, Provocation, supra note 3 at 14.

Federal/Provincial/Territorial Working Group on Provocation, Federal/Provincial/Territorial Working Group on Provocation Interim Report - British Columbia (1997), online: François Lareau $<$ http://www.lareau-law.ca/provocation.htm> [FTP, Interim Report]. See also NSW LRC, Report, supra note 12 at para. 2.115 [footnotes omitted]:

In addition to the literature review, a study of appellate court cases has been undertaken. During the course of a review of approximately 78 cases involving accused persons in an intimate relationship with the victim, or who claimed a homosexual advance was made by the victim, particular attention was paid to the nature of the provocation, the relationship of the [accused] to the victim with special attention to the gender and sexual orientation of the parties. The data available from this study suggests that while courts seem to have been quite open to accepting the proffered defence of provocation as having an air of reality about them such as to justify putting the defence to the jury, juries are not particularly prone to accepting such defences.

There have been a number of empirical studies in New South Wales which have considered (among other things) fatal assaults on women by their male partners. Most recently, the Judicial Commission examined the incidence of killing of sexual partners amongst sentenced homicide offenders in New South Wales within the period 1990 to 1993. The Judicial Commission's study revealed that 47 sentenced male offenders in that period killed their sexual partners. For five of those 47 male offenders, the defence of provocation was successfully raised to reduce liability from murder to manslaughter. In two of those five cases, the victim had allegedly provoked the male offender by hitting him. In the three remaining cases, the killing was the consequence of the victim leaving or threatening to leave the offender. In contrast, the study revealed that nine sentenced female offenders killed their sexual partners, eight of those nine female offenders having killed in response to physical abuse or threats by the victim immediately prior to the killing. All nine women were convicted of manslaughter, five of those nine having relied on the defence of provocation. The Judicial Commission concluded from these findings that there was little support for the proposition that juries routinely accept provocation defences by men who kill their female partners.

Dressler, supra note 185 at 745; Lee, "Response," supra note 140 at 303. a successful defence of provocation”: Justice Canada, Provocation, supra note 3 at 5-6; see also Lee, supra note 9 at 27. 
Female offenders were more likely to receive sentences involving "two years less one day" incarceration or less, including suspended sentences, sentences to be served in the community or probation (13 of 19 cases).

Sentences in the other six cases ranged from two to five years. ${ }^{211}$

The critics' concerns go far beyond any data set, and, in light of the sorry history of the treatment of women in the common law, cannot be dismissed with a few numbers. Nonetheless, the data does suggest that the law and juries can work. My burden throughout has been to show that provocation does serve a legitimate function in the law. If we are not to reject the project of law entirely - or, at least, if we are not to reject the defence of provocation entirely - steps can be taken to ensure that the defence operates to provide justice for accused and victims.

\section{Recommendations for ApPlying the Provocation Defence}

I can offer some recommendations relating to drafting, the judge's gatekeeper role, and the charge to the jury.

\section{A. DRAFTING}

The overall structure of the provocation provisions is sound: wrongful acts or words, context of suddenness, deprivation of power of self-control, action while in that state; successful invocation of provocation reduces what would otherwise be murder to manslaughter. ${ }^{212}$ "Insult" is adequately addressed in the case law. The provisions could be better integrated - as things stand, elements of the three main subsections must be crossreferenced to obtain the sense of the rule. The final two clauses in s. 232(3) ("legal right" and "incitement") ${ }^{213}$ should be broken out into their own subsections, instead of following the outmoded "proviso" format. The "heat of passion" and "passion” language is admittedly archaic and should be replaced by references to strong emotion (keeping in mind that the emotion generating provocation should not be confused with "ordinary" strong emotion). With the structural elements in place, substituting emotion for passion should not result in any significant changes to the sense of the doctrine.

While the relationship of acts that a person had a "legal right" to do and the notion of "wrongful act" could be clarified, I do not recommend re-establishing a category approach to provocation, either through exclusions from "wrongful acts" or through provisions that would have the effect of excluding certain acts from possibly supporting provocation. By way of illustration, the State of Maryland has used the statutory exclusion approach:

\section{§ 2-207. Manslaughter.}

(a) Penalty.- A person who commits manslaughter is guilty of a felony and on conviction is subject to:

Canada, Department of Justice, Report on Sentencing for Manslaughter in Cases Involving Intimate Relationships (2003), online: Department of Justice Canada <http://www.justice.gc.ca/eng/dept-min/ pub/smir-phiri/law-juri.html>.

Criminal Code, supra note 27, s. 232.

Ibid., s. 232(3). 
(1) imprisonment not exceeding 10 years; or

(2) imprisonment in a local correctional facility not exceeding 2 years or a fine not exceeding $\$ 500$ or both.

(b) Spousal adultery not a mitigating factor.- The discovery of one's spouse engaged in sexual intercourse with another does not constitute legally adequate provocation for the purpose of mitigating a killing from the crime of murder to voluntary manslaughter even though the killing was provoked by that discovery. ${ }^{214}$

Crafting legislation to anticipate the peculiarities of the evidence that may support a legitimate provocation claim is prohibitively difficult. Legislation should be general in nature; and it cannot anticipate the peculiarities of individual factual situations. ${ }^{215}$ In relation to the Maryland example, one might concede that discovery, by itself, would not be an appropriate ground for provocation. Yet, recall that Hunt J.A. believed that "[f]ew would dispute" that, in some circumstances, finding a spouse engaged in sex with a third party "could give at least an air of reality" to the wrongful act or insult element of the defence. ${ }^{216}$ The termination of a relationship, similarly, would not be an appropriate ground for provocation - "but there may be cases where one party torments another with remarks of an exceptionally abusive kind or where one party's behaviour puts quite exceptional emotional pressure on the other." 217 The advantage of the current approach to provocation is that the trial judge and the jury can make their determinations based on the particular evidence in particular cases. Provocation is an excuse, and excuses do involve consideration of individual sets of circumstances. ${ }^{218}$

By way of a caution against an exclusionary approach, Parliament did use a statutory exclusion model in the original Criminal Code "rape shield" rules:

246.6(1) In proceedings in respect of an offence under section 246.1, 246.2, 246.3, no evidence shall be adduced by or on behalf of the accused concerning the sexual activity of the complainant with any person other than the accused unless

(a) it is evidence that rebuts evidence of the complainant's sexual activity or absence thereof that was previously adduced by the prosecution;

(b) it is evidence of specific instances of the complainant's sexual activity tending to establish the identity of the person who had sexual contact with the complainant on the occasion set out in the charge; or

Md. Code. tit. 2 § 2-207 (2002), online: Michie’s Legal Resources <http://www.michie.com/maryland/ lpext.dll?f=templates\&fn=main-h.htm\&2.0>; see Lee, supra note 9 at 40 .

Lee, "Response,” supra note 140 at 305; Cynthia Lee, “The Gay Panic Defence” (2008) 42 U.C. Davis L. Rev. 471 at 550.

Tran, supra note 42 at para. 7.

LC, Partial Defences, supra note 69 at para. 3.147.

Lee, supra note 9 at 247. 
(c) it is evidence of sexual activity that took place on the same occasion as the sexual activity that forms the subject-matter of the charge, where that evidence relates to the consent that the accused alleges he believed was given by the complainant. ${ }^{219}$

The Supreme Court found that the legislation was unconstitutional since it denied the admissibility of evidence that could legitimately support defences:

\footnotetext{
Section 276 ... does not condition exclusion on use of the evidence for an illegitimate purpose. Rather, it constitutes a blanket exclusion, subject to three exceptions — rebuttal evidence, evidence going to identity, and evidence relating to consent to sexual activity on the same occasion as the trial incident. The question is whether this may exclude evidence which is relevant to the defence and the probative value of which is not substantially outweighed by the potential prejudice to the trial process. To put the matter another way, can it be said a priori, as the Attorney General for Ontario contends, that any and all evidence excluded by s. 276 will necessarily be of such trifling weight in relation to the prejudicial effect of the evidence that it may fairly be excluded?
}

In my view, the answer to this question must be negative. The Canadian and American jurisprudence affords numerous examples of evidence of sexual conduct which would be excluded by s. 276 but which clearly should be received in the interests of a fair trial, notwithstanding the possibility that it may divert a jury by tempting it to improperly infer consent or lack of credibility in the complainant. ${ }^{220}$

In the case of provocation, the danger with a categorical exclusion approach would be that circumstances that could legitimately support an excuse would be excluded. Difficulties would arise where properly exculpatory circumstances were connected with or "inextricably intertwined” with excluded categories of facts. I do recognize that since I have speculated that provocation, whatever its merits, is not a constitutionally protected defence, limitations on the availability of provocation (even if undesirable in some sense) could well survive Charter scrutiny.

\section{B. TRIAL Judge As GATEKEEPER}

Trial judges should ensure that they properly test whether provocation assertions have an "air of reality.” Provocation is a multi-component defence. Judges should ensure that each component has its evidential support. Moreover, provocation should occur only rarely. Few people kill, and an even smaller number will truly lose their self-control through objectively recognizable provocation at the time of forming the intent to kill. As the conditions for the excuse should rarely be met, so the defence should rarely be available on the evidence. This observation should not be translated into the imposition of a burden of proof on an accused to establish provocation to the satisfaction of the judge or to elevate the standards for passing the "air of reality" test. Judges should bring to their assessment the considerations mentioned in Parts III.B.2 and III.D.2, above. Judges should view the evidence carefully and critically and should be willing, if the evidence is insufficient, to rule against putting the defence to the jury. 


\section{CHARge TO THE JURY}

If provocation is put to the jury, the trial judge should instruct the jury on the appropriate (that is, respecting the cognitive element) and inappropriate (that is, respecting the volitional element) uses of evidence. ${ }^{221}$ If recognizing the defence would run contrary to any basic Canadian values, the trial judge should explain those values and their relationship to the ordinary person test. This latter recommendation is not contrary to Dickson C.J.C.'s decision in Hill, where he wrote as follows:

\footnotetext{
I should also add that my conclusion that certain attributes can be ascribed to the ordinary person is not meant to suggest that a trial judge must in each case tell the jury what specific attributes it is to ascribe to the ordinary person. The point I wish to emphasize is simply that in applying their common sense to the factual determination of the objective test, jury members will quite naturally and properly ascribe certain characteristics to the "ordinary person."222
}

Chief Justice Dickson did not forbid elaboration; he simply did not require it. The current standard form jury instruction thus directs judges to charge juries respecting attributes relevant to the cognitive element of the ordinary person test (although it tends to confuse the cognitive and volitional elements of the test). ${ }^{223}$ Chief Justice Dickson was referring to the "specific attributes" to be ascribed to the ordinary person. One might argue that an appreciation and understanding of fundamental Canadian values is not a "specific attribute" of an ordinary person (such as cultural or ethic identity), but a general attribute, an attribute of any ordinary person that should be taken into account regardless of the specific attributes ascribed to the ordinary person by the jury. The use of jury instructions dealing with the relevant fundamental values has been recommended by others. ${ }^{224}$

Cynthia Lee proposes an interesting innovation for the charge to the jury "switching." 225 The basic approach is this: the trial judge may discern that a provocation defence may turn, improperly, on a silent discriminatory premise — for example, that heterosexual men have a right to react with violence to a non-violent homosexual advance, or that men have a right to react with violence to control women with whom they have an intimate relationship. To determine whether an ordinary person would have lost self-control in the circumstances, the jury is asked to "switch" irrelevant (but illegitimately compelling) personal characteristics. In the case of a non-violent sexual advance, the jury could be asked to consider whether self-control would have been lost if the advance had been a heterosexual advance, or if the victim were a woman. In the case of domestic homicide, the jury could be asked to consider whether self-control would have been lost if the accused had been female and the victim had been male. If, after the "switch," any compulsion to violence evaporates, the jury members can see that this compulsion was based on illegitimate grounds.

The counter-factual nature of this reasoning may cause concern. First, the canonic instruction is that the ordinary person is to share the age and sex of the accused. Gender

Stuart, supra note 30 at 568.

Hill, supra note 4 at para. 37.

Canadian Judicial Council, supra note 59.

CBA, Recodification Task Force, supra note 37; FTP, Interim Report, supra note 209; Dressler, supra note 185 at 759-61; Westen, supra note 151 at 157.

Lee, supra note 9 at 277. 
switching would seem to violate that directive. The reason for attributing a gender to the ordinary person, though, is that gender is somehow morally relevant to determining how the ordinary person would behave. If gender is not morally relevant, then the ordinary person could be genderless. Gender could be an important contextual element, as when a woman is subject to sexual or physical attacks and, in the end, is provoked to kill her abuser. Also, in the case of a female accused, directing the jury members to put themselves in the position of an ordinary woman would serve to overcome or undermine any preconceptions that might arise from an unexamined male perspective. I note that asking male jurors to consider the ordinary person as female is already a form of "switching."

Second, one might oppose switching on the ground that juries should decide on the facts as they have been established, not on the basis of hypothetical facts. The propriety of using a jury instruction to dispel the prospect of erroneous stereotypical reasoning was approved by Major J. in the R. v. D.D. ${ }^{226}$ case. Moreover, it is entirely proper for judges to direct juries in an effort to overcome any prejudices or biases that might be elicited by evidence. Lee's technique could be understood as a variation of the traditional judicial "admonition" to the jury. ${ }^{227}$ Switching, moreover, is a common technique in moral reasoning ("how would you like it if it happened to you?”; "what if so-and-so tried to do that?”). We could expect jury members to use forms of switching in their deliberations as they reason through the evidence and the ordinary person's reactions in the circumstances. Lee's technique was in fact used in a jury instruction in Alaska v. Denarius Lockhart. ${ }^{228}$

Switching could be a useful tool for judges to employ in their discretion, given their assessments of the particular circumstances and the interests of justice in provocation cases.

\section{Conclusion}

The doctrine of provocation has been misused. It does, however, serve legitimate functions in specifying the degree of culpability of individuals who kill under extreme emotional pressure. The doctrine accommodates the complexity of being human. It has the endorsement of some 400 years of application in common law criminal courts. Survival alone is no guarantee of fitness, but the longevity of the doctrine in common law and legislation is some circumstantial evidence that the doctrine plays a useful role in the administration of criminal justice. Our application of the doctrine can and should be improved so that it yields results that we can call just, as opposed to results that devalue and degrade victims. We might wish that we were better creatures and that we did not need the doctrine of provocation. But until a change occurs, we are better off having the defence of provocation. 